Article

\title{
The Use of a Park and Ride System-A Case Study Based on the City of Cracow (Poland)
}

\author{
Elżbieta Macioszek*(D) and Agata Kurek (D) \\ Transport Systems and Traffic Engineering Department, Faculty of Transport and Aviation Engineering, \\ Silesian University of Technology, Krasińskiego 8 Street, 40-019 Katowice, Poland; agata.kurek@polsl.pl \\ * Correspondence: elzbieta.macioszek@polsl.pl; Tel.: +48-32-603-41-50
}

Received: 15 May 2020; Accepted: 3 July 2020; Published: 5 July 2020

\begin{abstract}
The park and ride (P\&R) parking type is usually located near peripheral public transport stops. These parking places are dedicated to people who, after leaving their vehicle in the parking, continue their journey to the city center using some form of public transport such as bus, metro, rail or tram systems. This article aims to examine the features associated with P\&R parking locations in use in Cracow (Poland). The analysis included the number of entries and exits to and from parking during particular periods of the day, week and year, parking time of vehicles, and parking space use. A parking peak hour factor was also calculated, which expresses the crowding degree of vehicle entries/exits in/out parking during a particular period. In addition, the paper presents an analysis of factors determining users to P\&R parking use. In the modeling process, logit models were used, which, as stated after analyzing the literature on the subject, were already used in various countries around the world to describe the behavior of P\&R parking users. However, so far, such research relating to Polish conditions has been not published in the available literature. The obtained results allowed to state that the most important factors determining the likelihood of using P\&R parking in Cracow are age, number of years having a driving license, monthly income (gross), and an average number of trips made during a day. Other variables, which not included in the study, can influence the P\&R parking use. However, the presented results are the basis for conducting furtherer, more in-depth analyses based on a larger number of independent variables that may determine the $P \& R$ parking use.
\end{abstract}

Keywords: parking; park \& ride; the use of park \& ride systems; parking peak hour factor; logistic regression model; road traffic engineering; road transport

\section{Introduction}

High traffic volumes in cities often lead to road congestion. Dense buildings and other terrain restrictions often not allow further development of the street network [1,2]. These conditions lead to the search and implementation of solutions aimed at limiting the number of passenger cars entering the city center. In many cities around the world, there is a tendency to build Park and Ride (P\&R) parking locations on the outskirts. They are designed to enable users to combine travel using their personal means of transport with means of public transport, thus contributing to reducing the number of passenger cars entering the city center (Figure 1). P\&R parking contributes to improving transport accessibility to city centers. In addition, the ecological awareness of societies is constantly growing that strive to live in an unpolluted environment, free from communication noise. 


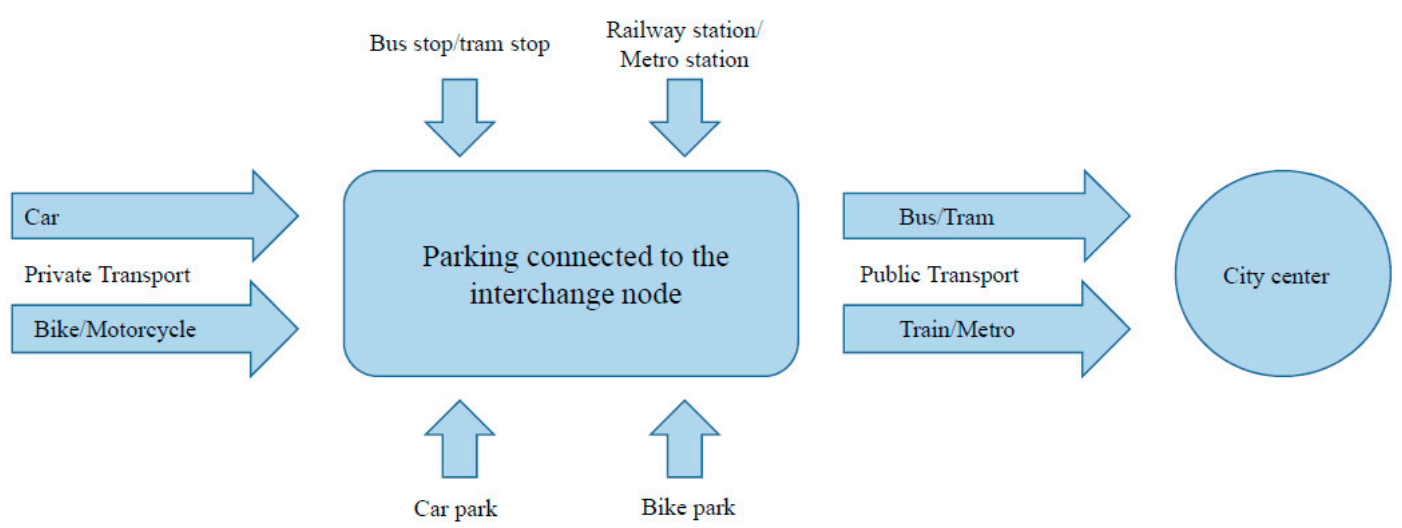

Figure 1. The idea of travels made using parking type $P \& R$ and various means of transport. Source: The authors, based on $[1,3]$.

P\&R parking also provides benefits to the drivers of cars, because in their travel they do not incur any time loss in road congestion or looking for a parking space. In addition, travel costs are reduced, because in crowded streets the speed is low, and thus, fuel consumption is higher. Also, drivers do not need to pay parking fees for leaving the car in the city center, because they can leave the vehicle in $P \& R$ parking, which is often free with a ticket for public transport, or the fee is relatively small.

On the other hand, during the process of planning the location of this type of parking, an important issue is the appropriate location and organization high-quality public transport, whose task is to encourage drivers to leave their cars in the $P \& R$ parking and to continue their journey using such public transport. Experience shows that P\&R parking should be located on the outskirts of cities near public transport stops, whereas, public transport should be adjusted to the needs of users in terms of travel comfort, frequency, regularity and reliability of service [4].

Practices also indicate the negative impact of $P \& R$ parking on the existing behavior of residents of the area. According to authors like Parkhust [5] and Karamychev and Reeven [1] P\&R parking can contribute to increased vehicle traffic on the outskirts of cities. People who have so far used only public transport, encouraged by the availability of newly built P\&R parking, may use a car for short trips to the P\&R parking and there change the means of transport to public transport.

This article aimed to examine the features associated with P\&R parking use in Cracow (Poland). The analysis included the number of entries and exits to and from parking during particular periods of the day, week and year, parking time of vehicles and parking space use. A parking peak hour factor was also calculated, which expresses the degree of crowding of vehicle entries/exits in/out parking during a particular period. In addition, the paper presents an analysis of factors guiding users to $P \& R$ parking use. In the modeling process, logit models were used, which, as stated after analyzing the literature on the subject, were already used in various countries around the world to describe the behavior of $P \& R$ parking users. However, so far, such research relating to Polish conditions has been not published in the available literature.

The article consists of eight sections. The first section is an introduction to the research topic. The second section contains a review of the literature on the subject in the field of research and analysis regarding P\&R parking, referring to both works from various countries around the world and Poland. The third section characterizes the adopted research area - i.e., the city of Cracow with the P\&R car parks located in its area. Section 4 describes the research methodology and the main objectives of the work. Section 5 contains an analysis of $P \& R$ parking use in Cracow. This analysis in particular included determination of features such as the average number of vehicles entering a parking on particular days of the week; the average number of vehicles entering parking on a particular month for working days; distribution of vehicle entries to and exits from the parking on working days; vehicle parking times on working days; the degree of use of parking space on working days as well as parking peak-hour factor for working days. In turn, analysis of factors determining the use of P\&R parking has been 
presented in Section 6. This section characterizes respondents, respondents' travel and use of P\&R parking, and presents the binomial logit model used in the modeling process, as well as logit model results. In the end, a discussion on the results obtained is presented, and conclusions from the research and analyses are made, indicating at the same time the need for further extensive research in this area.

\section{Review of the Literature on the Subject in the Field of Research and Analysis Regarding P\&R Parking}

The various aspects of the subject of $P \& R$ parking have already been mentioned many times. Scientific papers available in the literature refer mainly to such aspects as:

- modeling the behavior of P\&R parking users,

- analysis of factors influencing the choice of $P \& R$ parking,

- choice of location and capacity of P\&R parking and analysis of parking space usage.

Based on the analysis of the literature on the subject, it can be concluded that logit models are very often used in modeling the behavior of P\&R parking users. The analyses presented in research works from various countries around the world were mainly based on data obtained from surveys conducted among P\&R parking users and data from automatic systems used to operate P\&R parking sites.

Analyzing selected works, it can be stated that, e.g., Karamychev and Reeven [1] studied the impact of P\&R parking in The Netherlands on the disturbance of vehicle traffic using discrete modal selection. The results of their research indicate that the reduction of traffic in the city center (due to the P\&R parking construction) may cause people who have used public transport until now to use a car to get to the city center, encouraged by the improvement of traffic conditions. In addition, Karamychev and Reeven indicated that reduced road traffic in the city center may be accompanied by corresponding increased road traffic on the outskirts of the city. In turn, Bos and Molin [6] presented a logit model which was based on the choices of drivers: P\&R parking, car and alternative means of public transport. These studies indicate that the measures used to reduce the attractiveness of car predominate over measures that make the $P \& R$ parking the most attractive solution.

Modeling the behavior of $P \& R$ parking users is another thematic area covered in the subject of P\&R parking. In this group of works, we can mention the works of Qin et al. [7], who used decision field theory to construct a model describing the psychological decision-making processes of travellers. In turn, Sharma et al. [8] conducted research aimed at understanding the behavior of P\&R parking users. They developed two polynomial logit models. The first assumed that users choose solutions with maximum usability. The users have many options to choose and perceive a certain level of profit for each of them, then chooses the solution that is most useful to him. The second model assumed that when making decisions, users minimize losses compared to available alternatives. The conclusions of this study indicate that users choose the $P \& R$ parking that allows them to minimize travel time and cost. In turn, research on the preferences of $P \& R$ parking users was presented in a research work of Webb and Khani [9]. In this work, its authors compared the predictive abilities of the polynomial logit model, mixed logit model and nested logit model. Webb and Khani on the basis of the conducted research concluded that polynomial and mixed logit models best reveal the preferences of P\&R parking users. The results of their research prove that users prefer to spend more time travelling than travelling long distances.

Islam et al. [10] presented an analysis of factors influencing the choice of P\&R parking during travel. This analysis was made based on data obtained from surveys using polynomial regression analysis. The results presented in this work indicate that the factors influencing the choice of P\&R parking travel are travel time using public transport, total travel time using P\&R parking, and means of public transport and any parking fee near the destination. Similar studies were performed by He et al. [11], who also based on surveys sought the answer to the question of what features influence the P\&R parking use during travel. For this, they used a binary logit model. Based on the results from the model it was found that higher monthly income and longer duration of having drivers' licenses 
affect the less frequent use of the P\&R parking during travels, while road congestion and parking fees increase the P\&R parking use. In another work, Ying et al. [12] also presented a disaggregated model based on the results of surveys. The results indicated that the main factors affecting the behavior of P\&R parking users are traffic congestion, knowledge of the route, and lack of parking space. Survey data was also used to build utility function by He et al. [13]. According to the results of the conducted research, the authors indicated that the individual attributes of car users, travel characteristics, and the environment affect in various degrees the preferences of using P\&R parking. In their work Zhao et al. [14] presented a polynomial logit model for determining the probability of choosing a travel mode based on surveys. The logit model was also used by Hole [15], but it was a binomial model. Features that affect the selection of the P\&R parking as one of the travel elements were analyzed based on the data from the survey. Qin et al. [16] using structural equation modeling analyzed the relationship between factors affecting P\&R parking choice and the intention to use parking. Conclusions from the research carried out by Qin et al. indicate that $P \& R$ parking use is due to bad traffic conditions. The level of service in this parking type and the high comfort of traveling using public transport cause that more people use $P \& R$ parking.

Another group of works in the field of research on P\&R parking concerns the methodology for choosing the $P \& R$ parking localization and its capacity. In this group of research works we can mention, amongst others, Song et al. [17], who based on a numerical example, showed that the optimal localization and capacity of $P \& R$ parking encourages commuters to use a car to transit while using $P \& R$ parking. The problem of $P \& R$ parking localization was also presented in paper by Wang et al. [18]. The model presented in the work of Wang allows choosing the localization of the parking with maximum profitability of the parking functioning. In turn Fan et al. [19] developed two bilevel programming models for determining the location of P\&R parking, i.e., a higher-level model and the lower-level model. The higher-level model corresponds to the authorities' decisions regarding the location of parking lots. It aims to maximize social well-being. In turn, the lower-level model represents a stochastic balance of users, which simulates the behavior of commuters, and thus has an impact on the decisions on the location of higher-level P\&R car parks. Model results suggest that maximizing social well-being is beneficial for both authorities and users. Genetic algorithms were also used to determine the optimal location of P\&R parking at work by Khakbaz et al. [20]. Khakbaz et al. also used the genetic algorithm to determine the optimal number of parking spaces and the appropriate public transport offer. The results of their work indicate that locating P\&R parking along roads with high traffic levels and above the central business district may contribute to a reduction in traffic volume on the transport network.

In the case of research works related to determining the optimal location of P\&R parking, a group of research works can be distinguished that use the analytic hierarchy process (AHP) method for this purpose. For example, Alghazali et al. [21] used a nonparametric approach to check three aspects during the process of choosing the location of P\&R parking, which are: demand, the impact of major roads and transport accessibility of the area. The results of their research work indicated that demand has the greatest impact on the selection of P\&R parking locations. In turn, the impact of major roads and transport accessibility of the area are of two-fold importance. The purpose of the research was however not to find the right location for $P \& R$ parking, but to determine the weighting of factors related to the location of $P \& R$ parking. Another research work by Krasić and Lanovic [22], in which the locations of P\&R parking with the use of AHP were analyzed, concerned the city of Zagreb. The results presented in the paper indicate that the most significant criterion is the size of area gravitating to the $P \& R$ site, and the least significant criterion is the access to $P \& R$ parking facility. The procedure for locating new P\&R parking using the AHP method was also presented in the research work of Chen et al. [23]. The procedure consisted of two stages. The first stage concerned the selection of locations for the P\&R parking near the rail transit network. The second stage, however, was the assessment of new $P \& R$ parking and determining the detailed location for the proposed $P \& R$ parking. The AHP method and expert scoring method (ESM) were used to estimate the rank of the location of 
the proposed P\&R parking. For the analysis of each of the proposed locations, the following features were taken into account: population density, annual household income, accessibility to P\&R parking, distance from the city centre and saved time spent travelling.

In turn, Szarata presented in [24] the results of a study which aimed to estimate the number of potential users of the P\&R parking using the Delphic approach. In his next research work, Szarata [25] presented a methodology that allows to estimating the share of travel using the P\&R parking in city trips that were originally carried out by public and individual transport. This methodology was based on the results of surveys carried out using the Delphi method.

Chen et al. [26] on the other hand developed an application for mobile devices that helps P\&R parking users in choosing suitable parking to park their cars. For this purpose Chen et al. used a multi-criteria decision-making model.

In the case of functioning P\&R parking, to assess the degree of parking space using it is necessary to research the number of parking vehicles and parking time. Based on this type of data, it is possible to determine, i.a. vehicle rotation at parking spaces, degree of parking use, etc. This type of research was conducted in, i.a. Malaysia [27-29], China [14,30], USA [31,32] and Poland [33-35].

In Poland, P\&R parking sites have been built so far in only a few cities. They are mainly located in larger cities, i.e., in Warsaw [36], Cracow [37], Wrocław [38]. In some cities there is only a single P\&R parking, e.g., in Poznań [39], Tarnów [40], Tychy [41]. For this reason, there are few research works in Poland presenting results dedicated to P\&R parking. Analyzing the subject of the research works dedicated to P\&R parking in Poland, one can distinguish several works on the use of parking space, e.g., those by Kurek [33], Kowalski et al. [34], Bartel et al. [35] Brzeziński et al. [42]. Modeling and analysis of the location of P\&R parking is another research area raised in the Polish scientific literature on the subject. In this group of works, mention should be made of research works like those of Parkitny [43], Wiśniewski [44], Czerwiński [45], Fierek et al. [46], Lower et al. [47] and Szarata [48] and others regarding estimating the number of potential P\&R parking users (Szarata [24]); the share of travel using the P\&R parking in travels that were originally carried out using public and individual transport (Szarata [49]); determination of travel nuisance indicators using the P\&R parking at individual stages of the journey: by car, public transport, transfers between these two subsystems (Szarata [50]); comparative analysis of section travel time in the case of a functioning and non-functioning $P \& R$ parking (Szarata [51]).

The presented review of the research work indicates a wide range of research conducted in various countries around the world dedicated to P\&R parking. The research works on P\&R parking are characterized by the diversity, eg. of the research area, research sample, size of the research sample, the purpose of the conducted research, adopted methodology and obtained results. However, none of the papers published so far in the public available scientific literature on the subject, according to the best knowledge of the authors, has so far raised the issue of factors affecting the use of P\&R parking when travelling in Poland.

\section{Characteristics of the Research Area}

Cracow is a city with poviat status in the Lesser Poland Voivodship in the south of Poland. According to the data of the Central Statistical Office (in Polish: GUS) [52], in 2018 the number of inhabitants in Cracow was over 771,000 and the automotive index was 0.64 passenger car/person. Currently, there are 4 P\&R parking with public parking spaces, additionally, the construction of fifth parking is planned - P\&R Bronowice (Figure 2). 


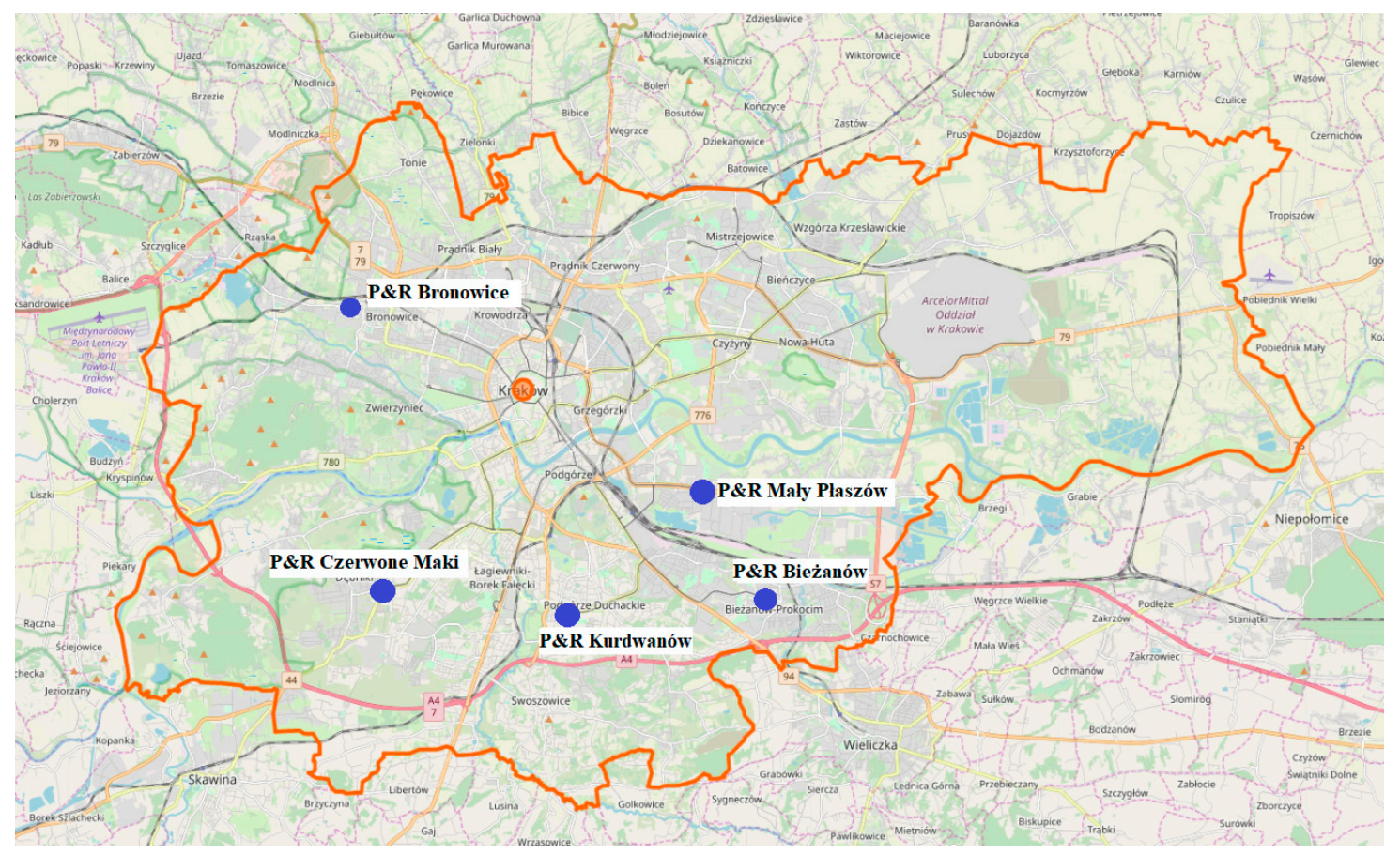

Figure 2. P\&R parking localization on the background of the city of Cracow. Source: The authors, based on [53].

These parking are open from 04:30 to 02:30 the next day. People with active cards with a valid ticket can leave their vehicles free of charge. Those are:

- Cracow City Card (physical medium),

- Cracow Card (physical medium),

- Lesser Poland Agglomeration Card (physical medium + mobile application iMKA),

- An electronic Student ID,

- An Electronic Doctoral ID.

Other people who use the parking are obligated to pay a fee of 10 PLN $(\sim 2.34 €)$. According to the Resolution of the Cracow City Council of 2012 [54] based on the ticket received, these persons may use the services of Public Transport in Cracow until 02:30 next day.

The next part of the article will present an analysis of the use of three parking spaces: the Bieżanów $P \& R$, Czerwone Maki P\&R, and Kurdwanów P\&R. Data for the analysis were obtained from the Municipal Infrastructure Management Sp. z o. o. in Cracow. Other parking were not included in the analyses, because the Mały Płaszów P\&R parking lot opened in April 2019 (hence the data for analysis would be disproportionate to the others), while the Bronowice P\&R parking site is just a planned investment. Table 1 presents the general characteristics of the analyzed parking, i.e.: date of parking opening, the number of available parking spaces, etc.

Figure 3 presents views of the analyzed parking. The main task of $P \& R$ parking is to allow leaving the car in parking located on the outskirts of the city and continue to travel using means of public transport. Table 2 presents the possibilities of changing to another means of transport offered in particular parking. Users of the analyzed $P \& R$ parking in Cracow have a choice of four means of public transport types. For bus and tram, the walking distance to the stops is small. In contrast, railway stations are located at a long distance from parking, which makes it difficult to change to this mean of public transport. 
Table 1. General characteristics of the analyzed P\&R parking in Cracow. Source: Own research based on [55].

\begin{tabular}{cccccc}
\hline Park \& Ride & $\begin{array}{c}\text { Date } \\
\text { of Opening }\end{array}$ & $\begin{array}{c}\text { Total Number } \\
\text { of Parking } \\
\text { Spaces }\end{array}$ & $\begin{array}{c}\text { Number of Parking } \\
\text { Spaces for People } \\
\text { with Disabilities }\end{array}$ & $\begin{array}{c}\text { Number of Parking } \\
\text { Spaces Equipped } \\
\text { with EV Charging } \\
\text { Devices }\end{array}$ & $\begin{array}{c}\text { Number of } \\
\text { Bicycle Racks }\end{array}$ \\
\hline Bieżanów & January 2018 & 110 & 5 & 2 & 20 \\
$\begin{array}{c}\text { Czerwone } \\
\text { Maki }\end{array}$ & November 2012 & 196 & 4 & 0 & 10 \\
Kurdwanów & December 2017 & 167 & 7 & 4 & 16 \\
\hline
\end{tabular}

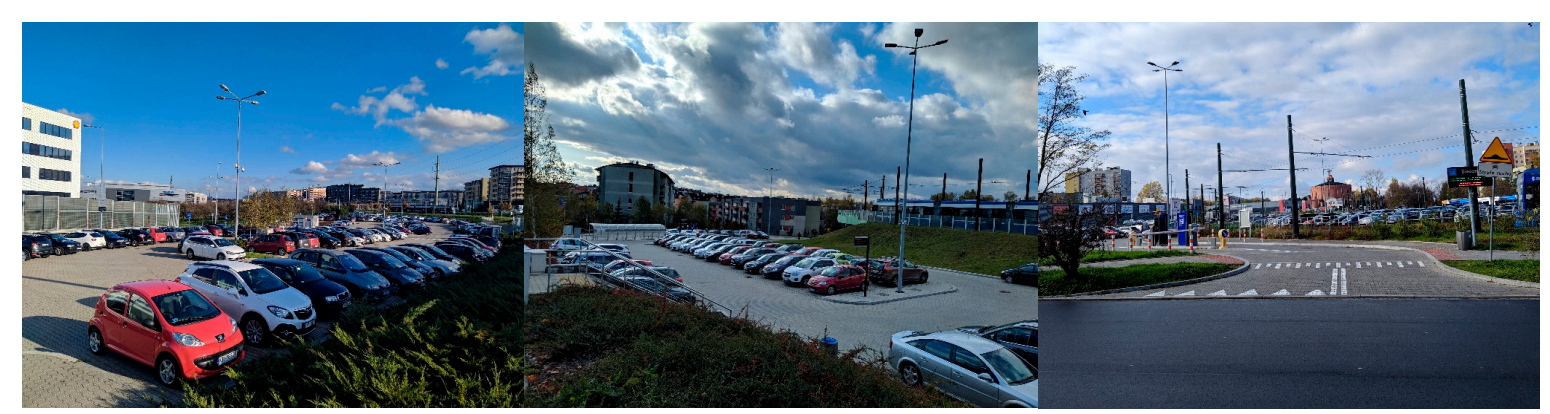

(a)

(b)

(c)

Figure 3. Views of the analyzed P\&R parking in Cracow: (a) Czerwone Maki; (b) Kurdwanów; (c) Bieżanów.

Table 2. Possibilities of changing the means of transport in the analyzed P\&R parking in Cracow.

\begin{tabular}{ccccc}
\hline Parking P\& R & $\begin{array}{c}\text { Tram Stop } \\
{[\mathbf{m}]}\end{array}$ & $\begin{array}{c}\text { Bus Stop } \\
{[\mathbf{m}]}\end{array}$ & $\begin{array}{c}\text { Bicycle System } \\
{[\mathbf{m}]}\end{array}$ & $\begin{array}{c}\text { Railway Station } \\
{[\mathbf{m}]}\end{array}$ \\
\hline P\&R Bieżanów & 20 & 80 & 550 & 800 \\
P\&R Czerwone Maki & 100 & 80 & 700 & 3120 \\
P\&R Kurdwanów & 110 & 55 & 150 & 1000 \\
\hline
\end{tabular}

An inventory of the P\&R parking equipment in Cracow was carried out in November 2019. Particular attention was focused on the information marking about parking localization (Figure 4a) and the marking of parking spaces. P\&R parking in Cracow characterized by good marking, which is important because users are correctly informed about the parking localization. The analyzed parking are with controlled access, they are equipped with devices of the Ticket Control System and the Toll Collection System (Figure 4b).

In addition to standard parking spaces, P\&R parking in Cracow also offers parking spaces for disabled people, electric cars (i.e., selected spaces are equipped with devices for charging electric cars) and bike parking (Figure 5). Individual types of parking spaces have complete horizontal and vertical markings. 


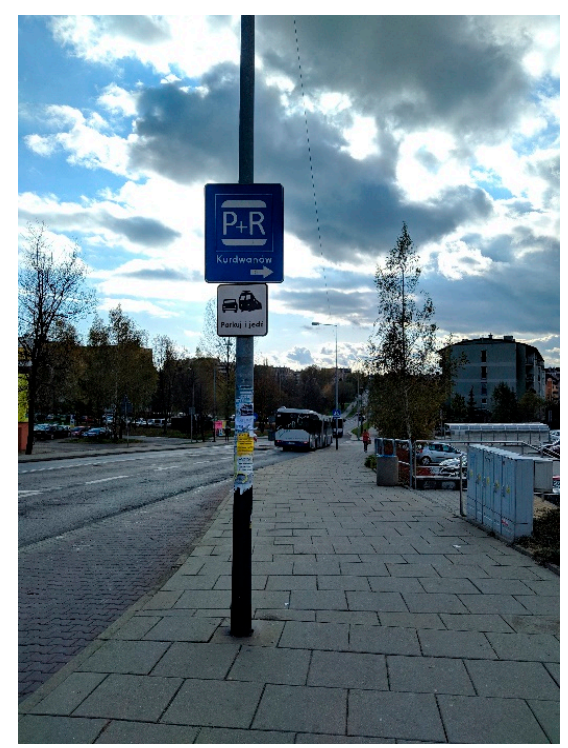

(a)

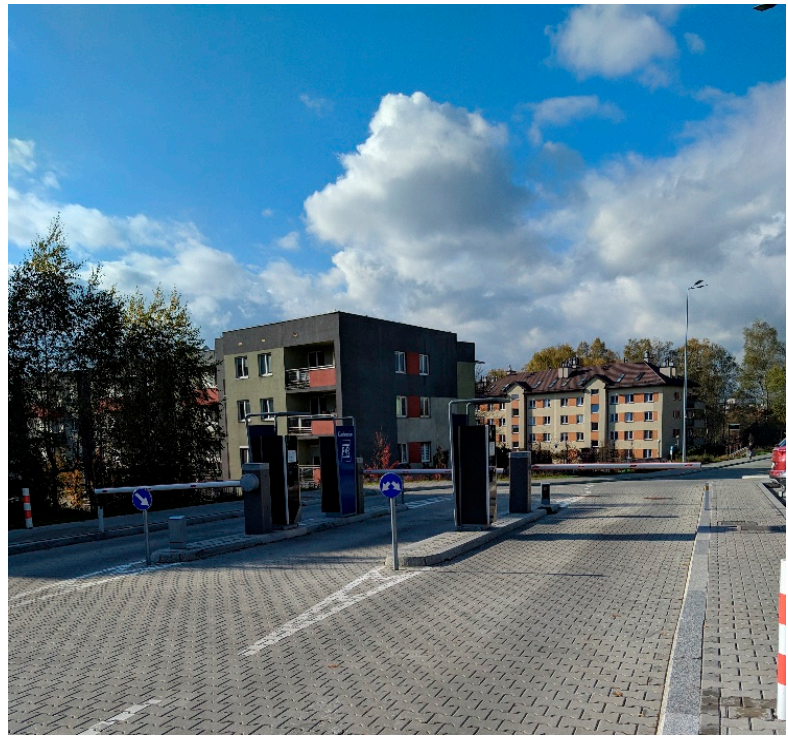

(b)

Figure 4. P\&R parking in Cracow; (a) example of parking location marking: (b) devices of the Ticket Control System and the Toll Collection System.

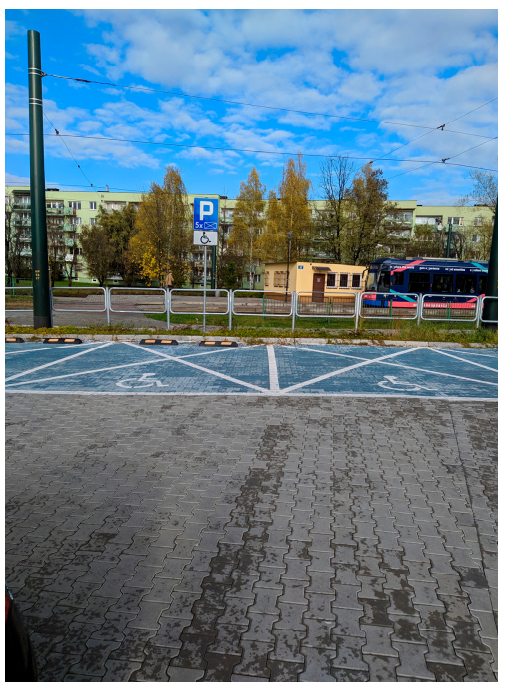

(a)

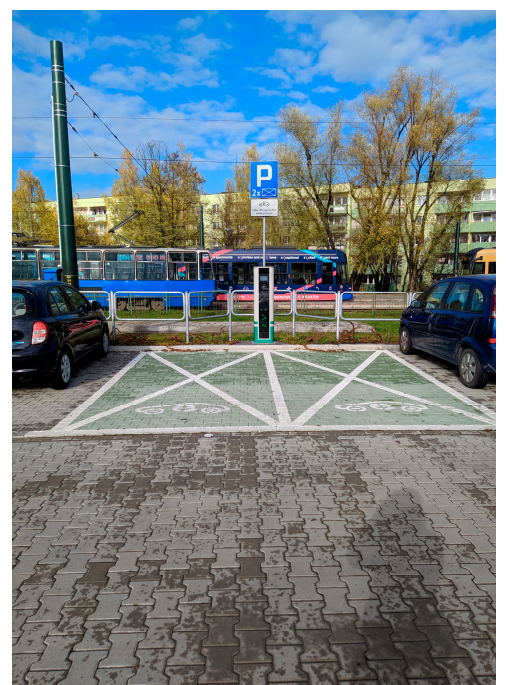

(b)

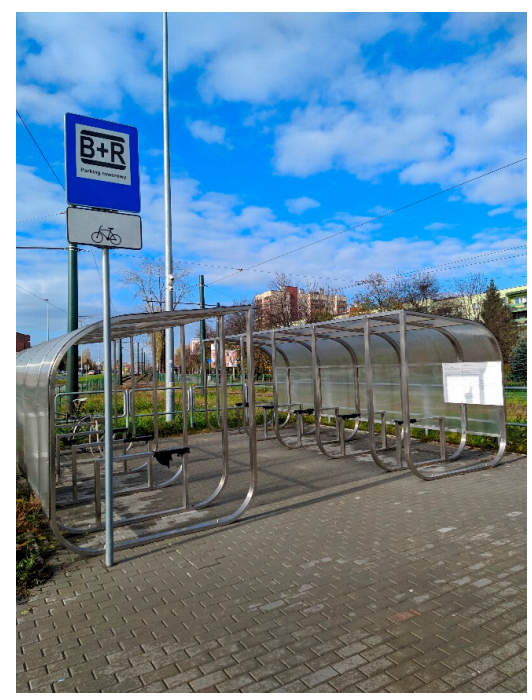

(c)

Figure 5. Examples of offered parking spaces in the P\&R parking Bieżanów in Cracow: (a) parking spaces for disabled people; (b) parking spaces for electric car drivers equipped with devices for charging electric cars; (c) bike parking.

\section{Research Methodology}

The main purpose of this work was:

- analysis of the P\&R parking in Cracow use,

- $\quad$ surveying preferences among users of the P\&R parking in Cracow,

- $\quad$ analysis of factors determining the P\&R parking in Cracow use.

Data for the analysis of the P\&R parking in Cracow use was obtained from Municipal Infrastructure Management Sp. z o. o. in Cracow. These data covered the functioning of the P\&R parking in 2018, i.e., contained information about the hours of vehicles entering and leaving the P\&R parking with an accuracy of one minute for each P\&R parking located in Cracow and for each day in 2018 (entry 
recording devices do not distinguish between the type of entering vehicle, so it is not possible to determine the type of an entering vehicle).

The research algorithm for the analysis of the use of P\&R parking has been presented in Figure 6 . This type of research has been used commonly in transport engineering. The survey questionnaire content and form were developed based on a broad literature review. The internal consistency of the questionnaire and its reliability were checked using the Cronbach's alpha coefficient $(\alpha)$ [56-62]. The value of this factor was equal to $\alpha=0.738$, which confirmed that the constructed survey questionnaire was a tool that could be used to measure the factors determining the $P \& R$ parking use. The final form of the survey questionnaire was assessed, discussed, and corrected by an expert team (five independent experts assessed its layout, style, readability, and transparency of questions). To assess respondents' answers a five-point Likert scale was used, from 1 (very insignificant) to 5 (very significant) [63-65]. The average rating for the questionnaire was received 4.4, which confirmed the satisfactory validity of the survey questionnaire. In turn, the analysis of factors that may affect the $P \& R$ parking use in travel was performed based on survey results. The researches algorithm for the analysis of factors that may affect the P\&R parking has been presented in Figure 7.

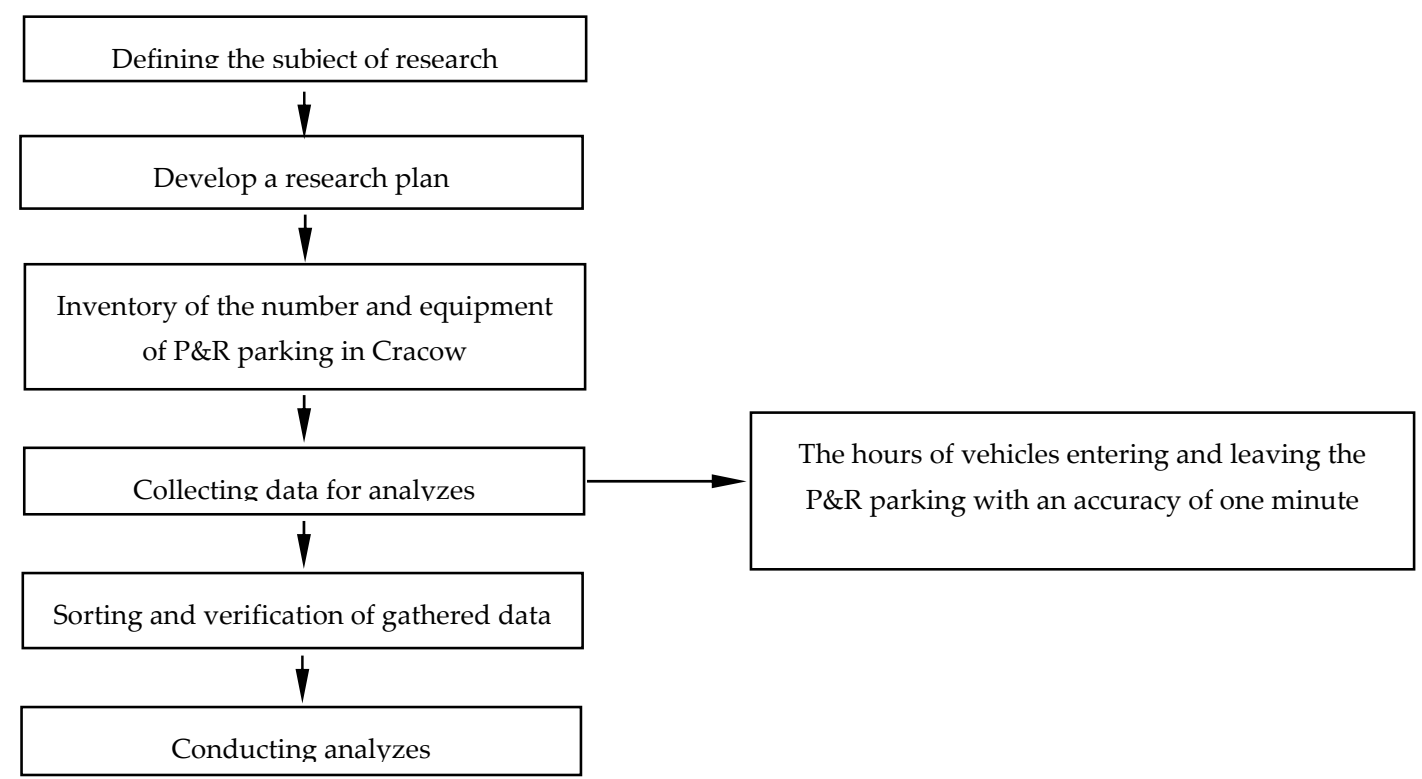

Figure 6. The research algorithm for the analysis of the use of $P \& R$ parking in Cracow.

The survey questionnaire consisted of several parts. In the survey, respondents answered questions about:

- data that characterized the respondent's profile: gender, age, education, monthly income, number of years having a driving license, etc.,

- characteristics of the respondents' journeys: average time (minutes) spent traveling during a day, the average number of trips made during a day, number of kilometers driven during a year, etc.,

- factors affecting the P\&R parking use, the answers used a five-point Likert scale, where: (1)-very insignificant; (2)-insignificant; (3)-significant medium; (4)-significant; (5)-very significant,

- travel patterns, including such information as: trip purpose (during weekdays and weekends), P\&R parking use during the travels, etc.

- $\quad$ solutions that would encourage respondents to use P\&R parking during travel. 


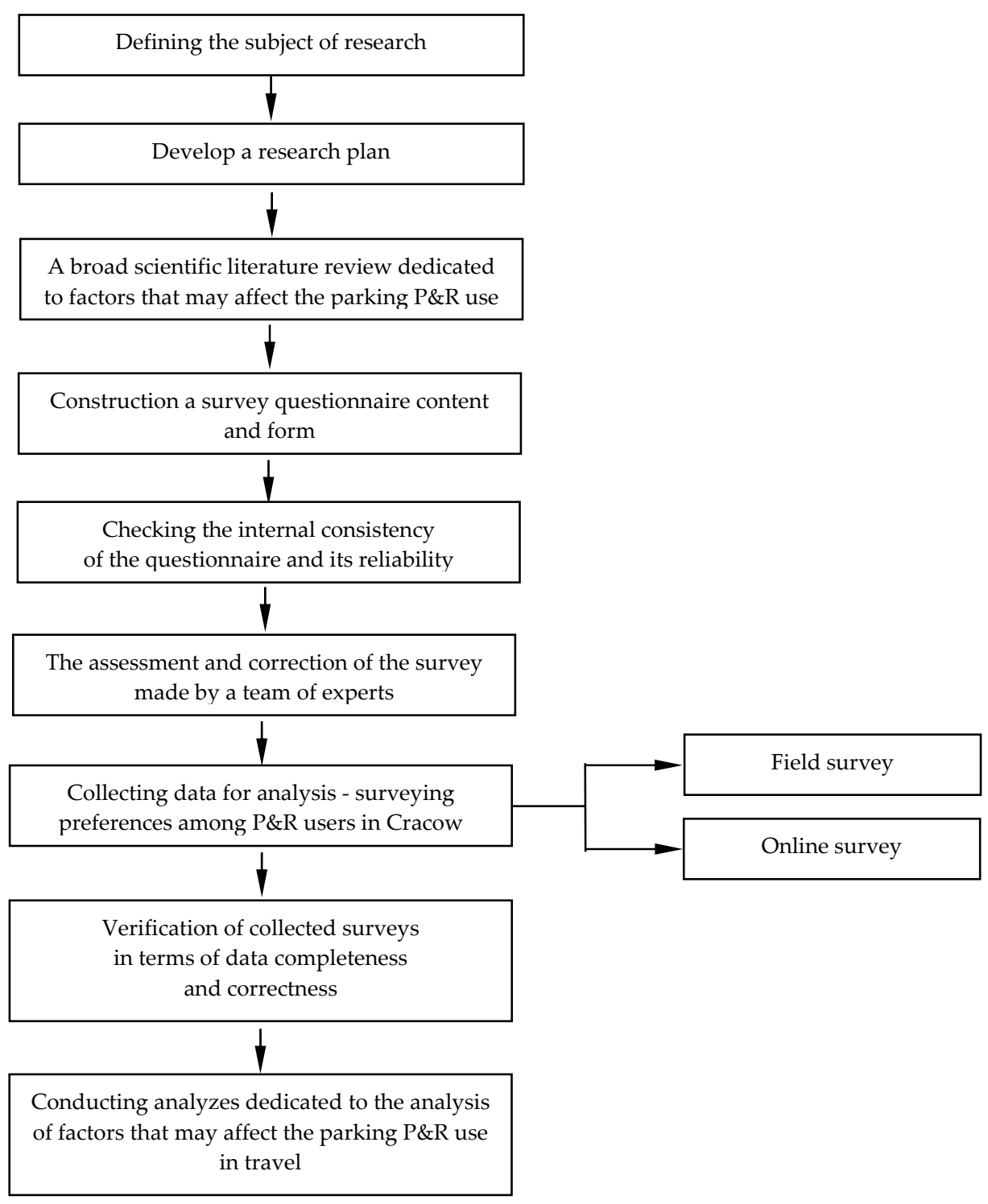

Figure 7. The research algorithm for the analysis of factors that may affect the P\&R parking use.

The research was carried out in 2018-2019 among Cracow residents and the surrounding area. In total, 1354 questionnaires were obtained, of which 1089 were obtained in field studies, while 265 were obtained from online surveys. In field studies, all persons participating in the survey had previously agreed to participate in the survey. The survey was conducted on weekdays and weekends in different periods of the day in order to obtain a large size and varied answers of the respondents. Due to the fact that subject of the study were drivers who can use P\&R parking, persons with driving license and traveling by car were examined. In Poland, a driving license is issued to persons from 18 years old, therefore persons from 18 years old were examined. The random sampling technique was used in order to select the respondents. In turn, the online survey was developed using the Survio tool that allows to design survey [66].

Collected survey questionnaires were examined in terms of data completeness and correctness e.g., the survey questionnaires were rejected in which it was found that respondent did not answer all questions as well as those in which respondents answered the questions e.g., "I do not know" or "I do not remember", "I have no opinion of my own", respondents said that they contained incomplete information; respondents could not indicate their assessment, respondents indicated that they were using the P\&R system for the first time, etc. A total of 1275 survey questionnaires remained in the 
database as a result of the selection. These data were the basis for analysis. After studying the literature on the subject, it was found that the logistic regression model was often used to analyze the factors determining the $P \& R$ parking use. The logistic regression model allows examining the influence of many independent variables $\left(X_{k}\right)$ on the dependent variable $Y$. The dependent variable has only two values and is dichotomous. These two values are coded as 1 and 0 , where: value 1 means having a feature, and 0-no having feature [67-69]. In connection with the above, based on data obtained from surveys, an attempt was made to determine the factors determining the $P \& R$ parking in Cracow use. A logistic regression model was used in the modeling process.

\section{Analysis of the P\&R Parking Use in Cracow}

An analysis of the P\&R parking in Cracow use was made for the period from March to December 2018 (the months: January and February have not been included in the analysis of the functioning of parking due to incomplete data). The analysis included the determination of the values that allow the characteristics of the functioning of parking in the analyzed period, which in particular included the determination of:

- the average number of vehicles entering parking on particular days of the week,

- the average number of vehicles entering parking on a particular month for working days,

- distribution of vehicle entries and exits to parking on working days,

- vehicle parking times on working days,

- the degree of use parking space on working days,

- parking peak-hour factor for working days.

The analyses did not include the days on which public holidays affect. These days were in 2018 working days and were before or after public holidays. A significant impact of the public holiday on the parking use was observed for them, which characterized by a visible decrease in the number of parked vehicles compared to the average number of parked vehicles on other days of the week (Table 3).

Table 3. Public holidays and days on which public holidays affect, which were not included in the analysis.

\begin{tabular}{|c|c|c|}
\hline Month & Public Holidays & Days on Which Public Holidays Affect \\
\hline March & - & 30 and 31 March-the impact of Easter \\
\hline April & $\begin{array}{c}1 \text { April-Easter } \\
2 \text { April-Easter Monday } \\
1 \text { May-Labour Day }\end{array}$ & 30 April—the impact of May holidays \\
\hline May & $\begin{array}{l}3 \text { May-Constitution Day } \\
10 \text { May-Whit Sunday } \\
31 \text { May-Corpus Christi }\end{array}$ & 2 and 4 May_the impact of May holidays \\
\hline June & -1 & - \\
\hline July & - & - \\
\hline August & 15 August-Armed Forces Day & - \\
\hline September & - & - \\
\hline October & - & - \\
\hline November & $\begin{array}{l}1 \text { November-All Saints' Day } \\
11 \text { November-Independence Day } \\
12 \text { November-after Independence Day }\end{array}$ & 2 November-the impact of All Saints' Day \\
\hline December & $\begin{array}{l}25 \text { December-Christmas Day } \\
26 \text { December-Second Day of Christmas }\end{array}$ & $\begin{array}{c}24 \text { December-Christmas Eve } \\
27 \text { and } 28 \text { December-the impact of } \\
\text { Christmas holidays } \\
31 \text { December-New Year's Eve }\end{array}$ \\
\hline
\end{tabular}


During data analysis, it was also observed that on some days the number of vehicles in P\&R parking is much lower than on other days, which was related to local events in the city in 2018. Accordingly, these days have not been included from the statements.

\subsection{Distribution of the Number of Entries and Exits to Parking over Time}

Figure 8a presents the average number of vehicles that used individual parking in the analyzed period on particular days of the week. In the analyzed period, the most number of vehicles used the Czerwone Maki P\&R parking and the least number of vehicles use the Kurdwanów P\&R parking. On working days there were more vehicles in all parking compared to weekend days. The average number of parked vehicles on particular working days in individual parking is similar (the same conclusion applies to weekend days).

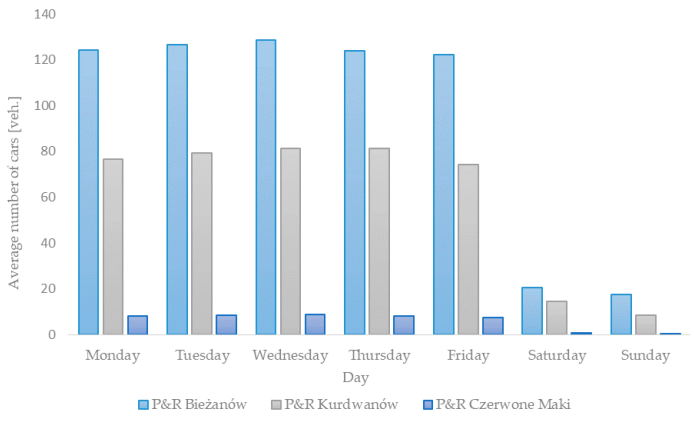

(a)

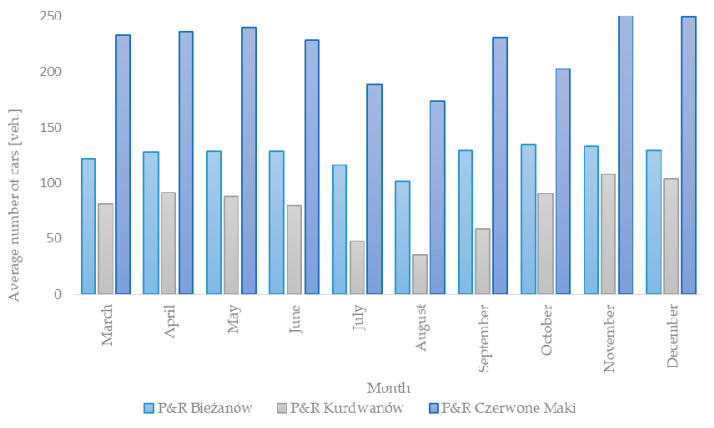

(b)

Figure 8. The average number of vehicles in the analyzed parking divided into: (a) days of the week;

(b) months of the year.

In turn, Figure $8 \mathrm{~b}$ shows the average number of vehicles that used parking on working days in particular months. In all parking, a decrease in the number of parked vehicles can be observed in the summer months (July and August) compared to other months. In addition, in the case of the Kurdwanów P\&R parking, the months of October, November, and December were characterized by greater use of parking space than other months. This may be due to the fact that this parking was launched in December 2017 and at the beginning of 2018 users may not yet have known about its existence. As can be seen in Figure 8a on working days, the P\&R parking in Cracow use is higher than on weekends, hence further analysis was carried out only on working days.

Figure 9 shows the distribution of the number of vehicle entries and exits into individual parking lots. Based on the data presented in Figure 9, it can be concluded that for each analyzed parking, the largest number of entries to the parking were recorded in the time interval from 06:00 to 09:00, while the most exits from the parking were in the time interval between 15:00-19:00. In Poland, at the accepted working hours, the morning peak hour usually occurs between 06:00 and 09:00, while the afternoon peak hour-14:00-17:00. Hence the obtained results confirm the fact that people entering to $\mathrm{P} \& \mathrm{R}$ parking during the morning rush hour and the exiting from $\mathrm{P} \& \mathrm{R}$ parking in the afternoon rush hour are probably residents commuting to the city center to and from work, school, or university.

Figure 9 also indicates that for individual parking sites, the morning and the afternoon hours when the most vehicles entered and exited the parking are slightly different in time. This could be caused by their localization and local conditions. In turn, the least vehicles in individual parking sites entered and exited at night, i.e., from 23:00 to 04:00. 


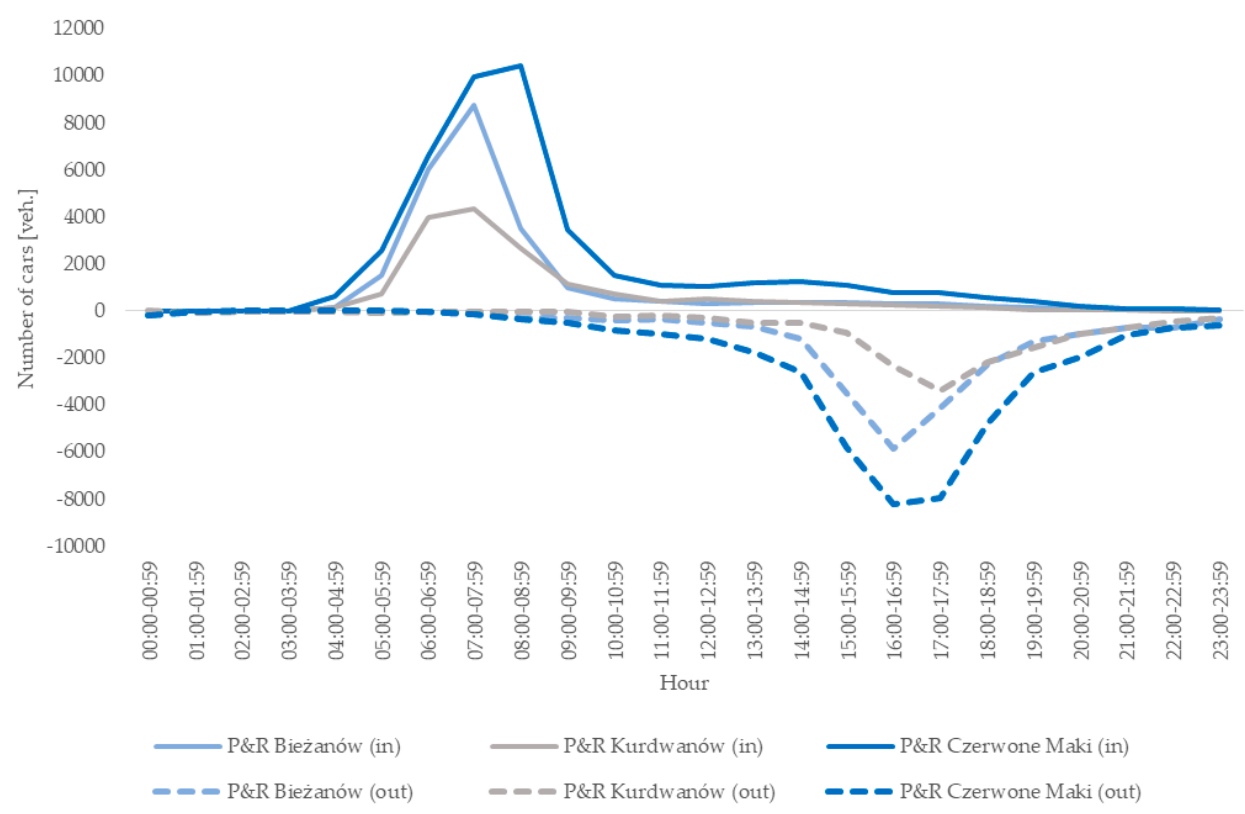

Figure 9. The number of vehicle entries (in) and exits (out) on working days at P\&R parking in Cracow for all analyzed parking.

\subsection{Analysis of Vehicle Parking Time and use of Parking Space}

Figure 10 shows the distribution of vehicle parking times in the analyzed parking sites on working days. The parking locations are open from 04:30 to 02:30 the next day, therefore the longest possible parking time is twenty-two hours. In the analyzed parking places, users usually leave their vehicles for more than eight hours. This fact again indicates that the majority of people using P\&R parking are people who commute to work, school, or university. In addition, leaving the vehicle for a short time (up to $30 \mathrm{~min}$ ) is more common than for periods from $1 \mathrm{~h}$ to $7 \mathrm{~h}$. Such short parking times are probably because near the parking places there are public buildings such as schools, kindergartens, clinics, where people entering the parking lots can pick up a passenger, or small local stores (e.g., bakeries, newsstands) where people are likely to shop quickly.

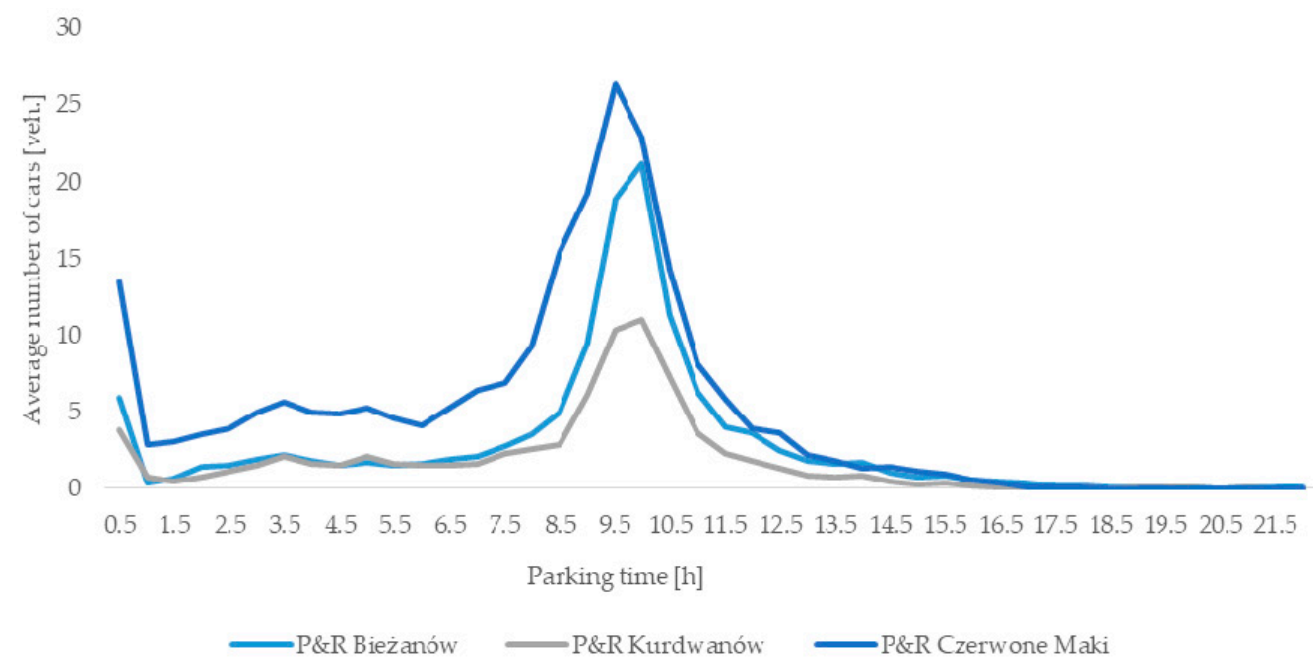

Figure 10. Distribution of vehicle parking time at $P \& R$ parking in Cracow on working days for all analyzed parking. 
In a further stage of work, the use of parking space in the analyzed parking was analyzed (Figure 11), whose value was determined from the formula:

$$
W=\frac{Z}{P} \cdot 100 \%
$$

where $W$ - use of parking space [\%], Z - number of parked vehicles [Vehicle] and $P$ - parking capacity expressed in the number of parking spaces [Parking space].

a). All analyzed P\&R locations

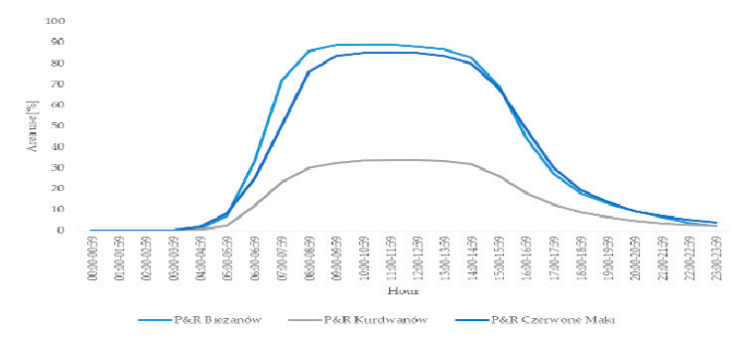

c). Bieżanów P\&R

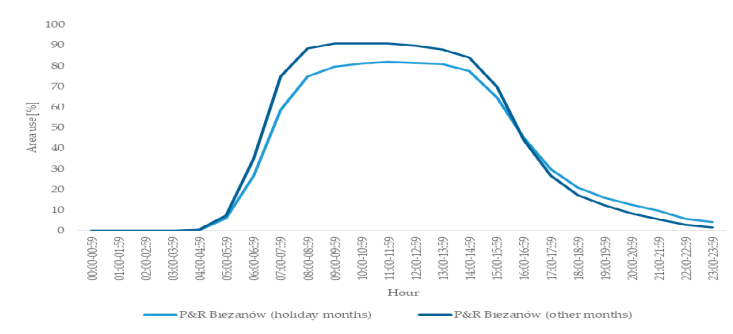

b). Kurdwanów P\& R

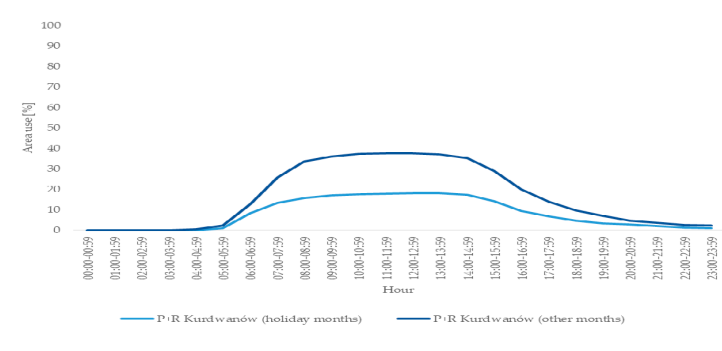

d). Czerwone Maki P\&R

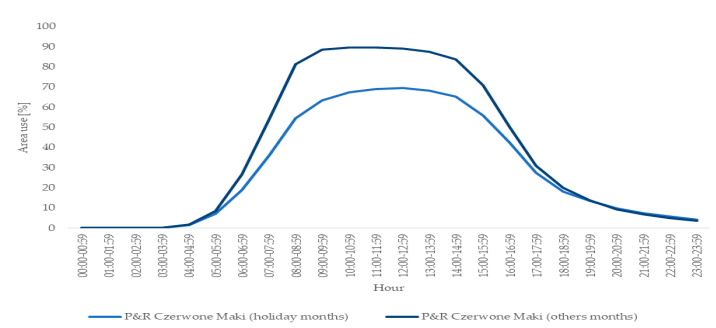

Figure 11. Parking rate on working days for: (a) all analyzed P\&R parking sites; (b) Bieżanów P\&R parking; (c) Czerwone Maki P\&R parking; (d) Kurdwanów P\&R parking.

In the analyzed period, the Bieżanów P\&R parking featured the largest parking space use. The Czerwone Maki P\&R parking has a little less use, while the Kurdwanów P\&R parking had only a small use of the parking space, which during the most in demand period of the day amounted to only 30\%. The heaviest use of parking space in the analyzed parking spaces occurs between 07:00 and 16:00 (above 70\% for the Bieżanów P\&R parking and Kurdwanów P\&R parking, above 20\% for the Czerwone Maki P\&R parking).

Figure 11a shows the degree of parking space usage on working days for the analyzed parking lots. Due to the fact that during the typical holiday months (July and August) traffic is characterized by different purposes, the parking space use was analyzed, distinguishing between holiday months and other months. The results of the analysis for individual parking are presented from Figure 11b-d. In the case of the Bieżanów P\&R parking, the difference in the parking space use between the holiday months and other months fluctuates around $10 \%$ in the most charged period of the day. Additionally, in the case of the Bieżanów P\&R parking during summer months there is a greater parking space use in the evening (18:00-24:00) than during other months. This may be because during the summer months various types of cultural and entertainment events are organized in the open air, e.g., in the Polish Aviators Park in Millenium Park, on the Nowa Huta Lagoon, which can be easily and quickly reached using public transport stops near the Bieżanów P\&R parking lot.

At the $P \& R$ parking Czerwone Maki and $P \& R$ parking Kurdwanów the difference in the parking space use during the holiday months and other months is greater than in the case of the P\&R parking Bieżanów and in the most demanded period of the day in both cases is about $20 \%$. 


\subsection{Parking Peak-Hour Factor for Park E Ride Parking in Cracow}

Usually, the peak hour factor compares the traffic volume during the busiest 15-minutes of the peak hour with the total traffic volume during the peak hour. Peak hour factor is often determined for different types of intersections (e.g., [70-78]) and for roads (e.g., [79-81]). It is also used in the analysis of space-variation of passenger flow (e.g., [82]). Research indicated that the peak hour factor has a strong impact on traffic analysis results.

In the case of P\&R Parking, the parking peak hour factor $\left(P_{\mathrm{PH}}\right)$ compares the traffic volume during every hour of the day with the total traffic volume during the day on the P\&R parking. This factor shows the uneven traffic intensity of vehicles entering and exiting the parking at a particular period of the day and can be designated as:

$$
P_{P H}=\frac{\bar{V}_{i}}{\bar{V}_{j}} \cdot 100[\%],
$$

where $P_{H F}$ - parking peak-hour factor [\%], $\overline{V_{i}}$ - the average number of vehicles entering or exiting the P\&R parking at the i-th hour [Veh./h] and $\overline{V_{j}}$ - the average number of vehicles entering or exiting the $P \& R$ parking on $\mathrm{j}$-th day [Veh./24h].

Figure 12 presents the parking peak hour factor values for the average values of vehicle entries and exits on/from parking on particular working days. The parking peak hour factor is expressed by distribution and proportion, which can visually show the crowding degree of vehicle entries and exits to/from P\&R parking locations in Cracow on particular working days at different time points.

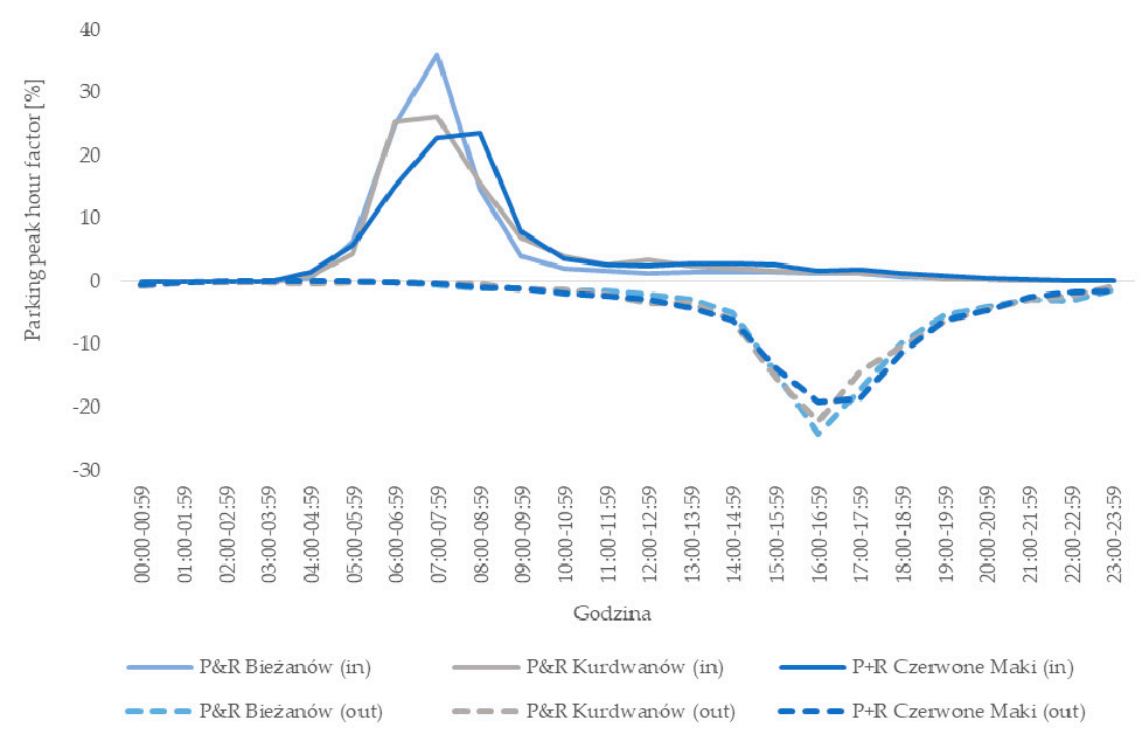

Figure 12. Parking peak-hour factor for $P \& R$ parking in Cracow.

Analyzing the data presented on the Figure 12 it can be stated that they confirm the results obtained earlier and which were presented in Figure 9 regarding the distribution of the number of entries and exits of vehicles to individual parking. In addition, the highest value of the coefficient for vehicles entering parking is from 06:00 to 08:00. In the case of the Kurdwanów P\&R parking, these are 06:00-08:00 (which is: 06:00-25\%, 07:00-26\%, 08:00-16\%), Bieżanów P\&R- 06:00-08:00 (which is: 06:00-25\%, 07:00-36\%, 08:00-15\%), while for the Czerwone Maki P\&R they are 07:00-09:00 (which is: 07:00-15\%, 08:00-23\%, 09:00-24\%). In the case of vehicles exiting the parking, the factor reaches maximum values between 15:00-18:00, in the parking places as follows: Kurdwanów P\&R 15:00-18:00 (which is: 15:00-15\%, 16:00-22\%, 17:00-14\%, 18:00-10\%), Bieżanów P\&R 15:00-18:00 (which is: 15:00-14\%, 16:00-24\%, 17:00-17\%, 18:00-10\%), Czerwone Maki P\&R (which is: 15:00-14\%, 16:00-19\%, 17:00-19\%, 18:00-11\%). 


\section{Analysis of Factors Determining the Use of P\&R Parking}

\subsection{Characteristics of Respondents, Respondents Travel and Use of PER Parking}

Figure 13 presents the characteristics of respondents divided into persons who use and do not use P\&R parking in Cracow. Most answers were obtained from men under 45 years of age, with secondary or higher education, whose monthly income is more than 3000 PLN $(\sim 650 \mathrm{E})$, who have had a driving license for at least six years. In addition, these people in most cases make less than four trips a day, their average travel during a day is less than $120 \mathrm{~min}$, the distance driven by car during a year less than $20,000 \mathrm{~km}$ and their travel purpose is obligatory (study or work). Other trip purposes such as shopping, social meeting, family meeting, healthcare, etc. classify as optional. In many cases, the share of people using P\&R parking places in particular response groups is at a similar level as for people who not using P\&R parking. Larger differences occur for questions about age, monthly income, and trip purpose. A significant proportion of respondents aged 45 and older said they use P\&R parking, as is the case with monthly income below 3000 PLN and for trips with an obligatory purpose.

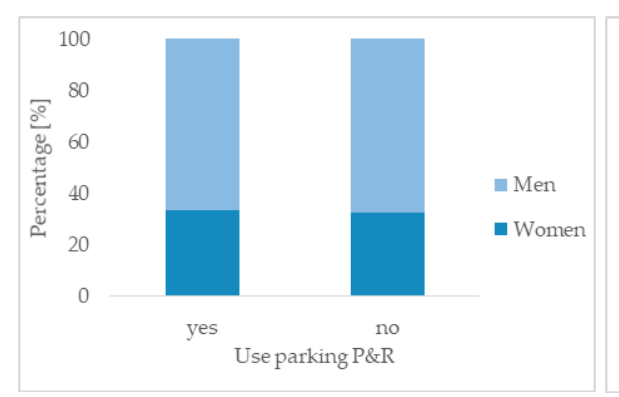

(a)

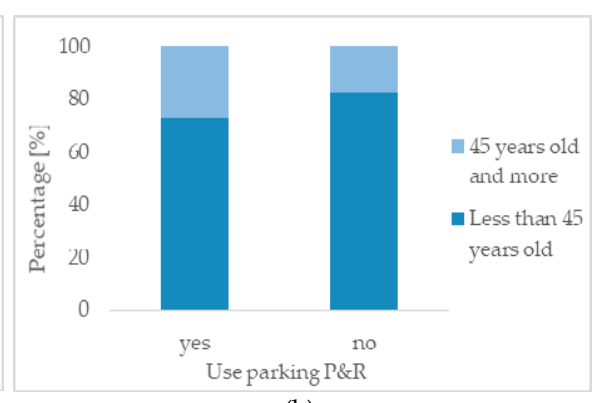

(b)

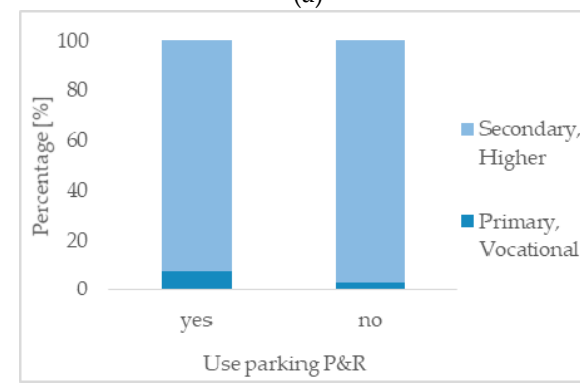

(c)

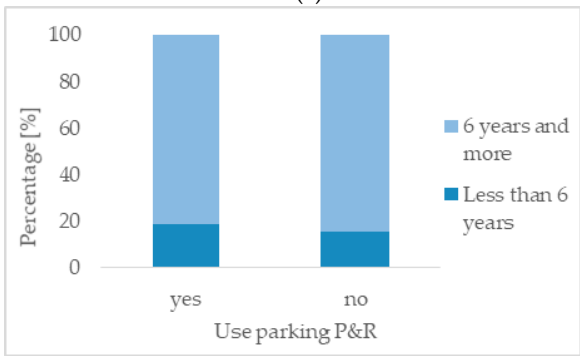

(e)

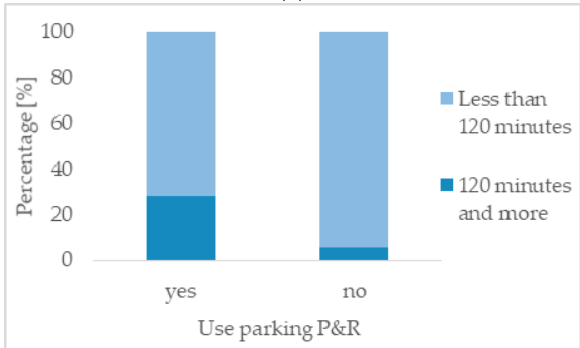

(g)

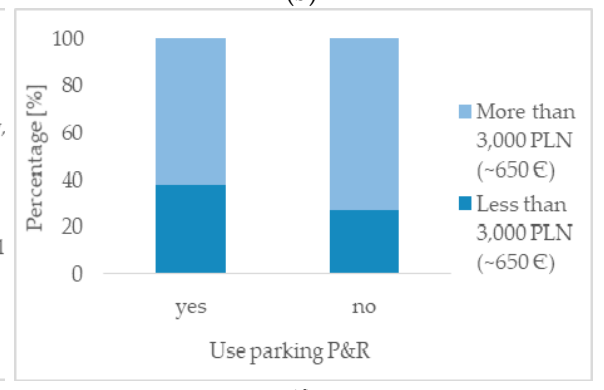

(f)

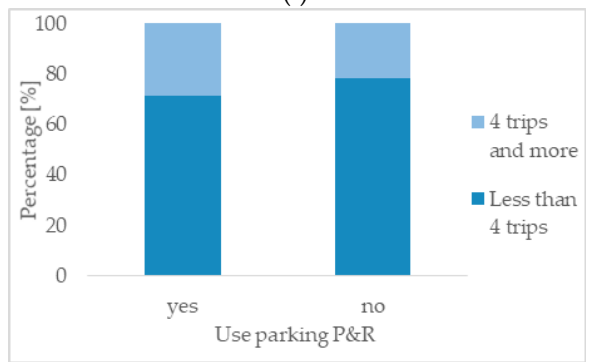

(f)

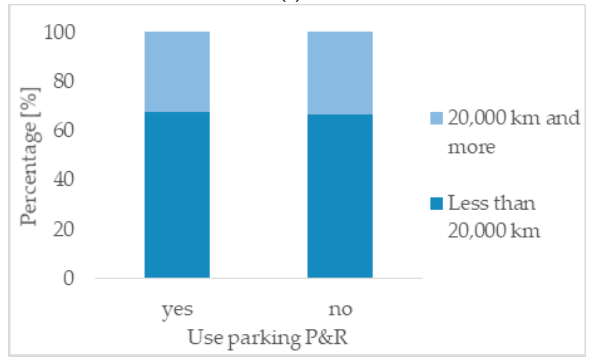

(h)

Figure 13. Cont. 


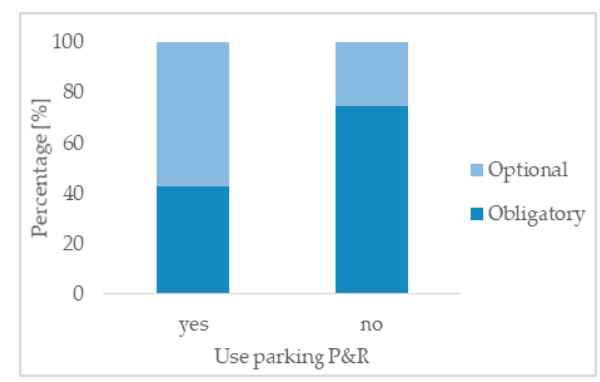

(i)

Figure 13. Characteristics of respondents using and not using $P \& R$ parking in Cracow depending on the following characteristics of the respondents: (a) gender; (b) age; (c) education; (d) monthly income (Gross); (e) the number of years of having a driving license; (f) the average number of trips made during a day; $(\mathrm{g})$ the average time spent traveling during the day $(\mathbf{h})$ the number of kilometers driven during a year; (i) trip purpose.

Respondents were also asked to indicate factors that were important for them when they making decisions about using P\&R parking in Cracow among such factors as: the quality of public transport services offered, the occurrence of road congestion, the availability of parking spaces near the destination, amount of toll, fuel price, route knowledge, road stress, and weather conditions.

The respondents could assign values from 1 to 5 (1-insignificant, 5-very significant) for each answer. Figure 14 presents the average values for individual factors. The data shows that the most important for respondents are road congestion, parking availability near their destination, and the quality of public transport services offered. However, road knowledge, road stress, and weather conditions proved to be the least important.

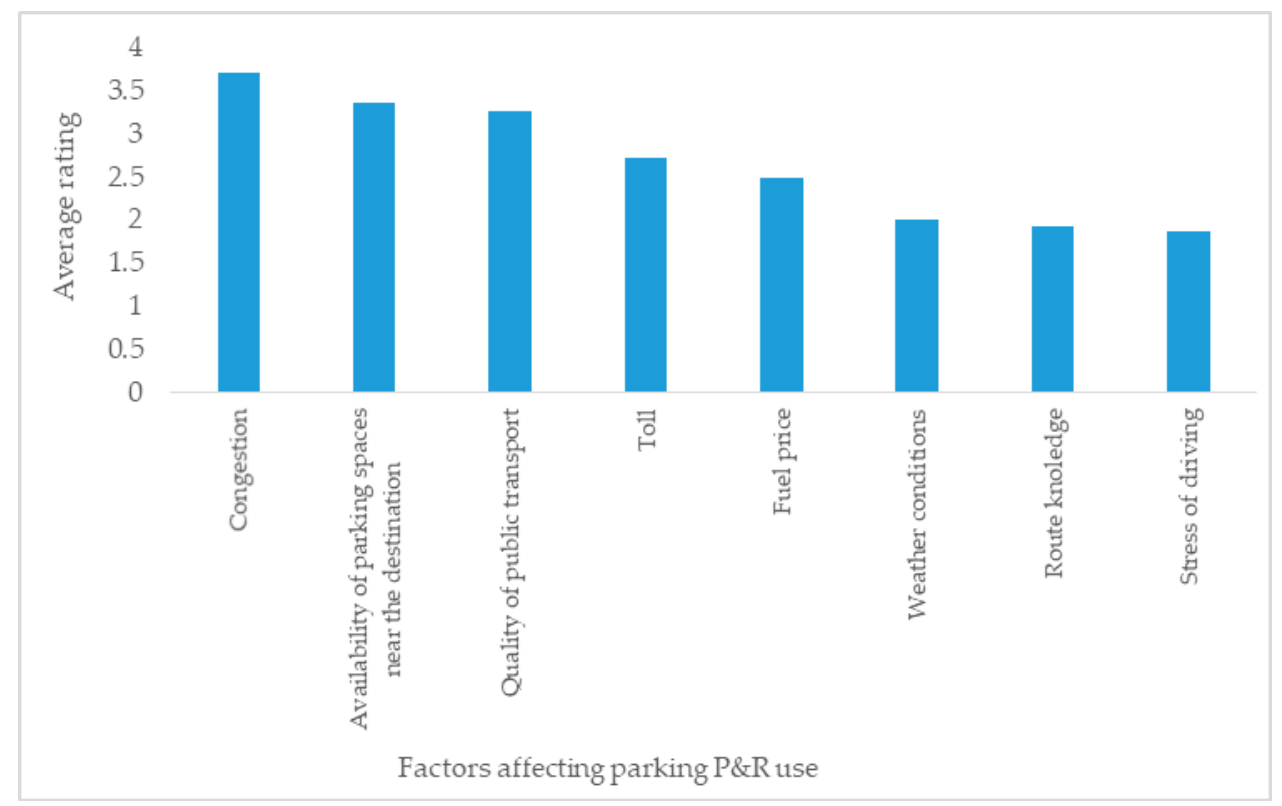

Figure 14. Factors affecting the use of $P \& R$ parking in the opinion of respondents.

Respondents who did not use P\&R parking were asked to indicate factors that could contribute to the P\&R parking use during travel. Almost 50\% (45.83\%) of respondents indicated better quality of public transport. Other answers included free public transport, fuel savings, another, more convenient location for the P\&R parking (Figure 15). 


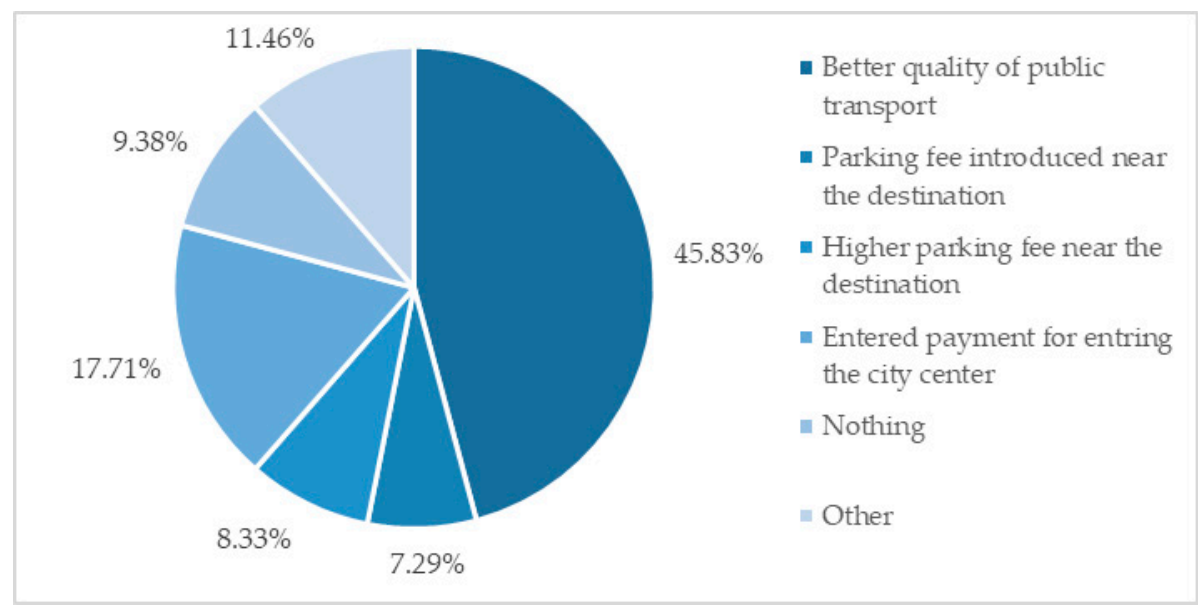

Figure 15. Solutions that, in the respondents' opinion would contribute to the P\&R parking use.

\subsection{Binominal Logit Model}

Logit models are used to explain qualitative variables depending on the level of exogenous variables (qualitative or quantitative). They find important applications, among others in modeling the finding of the unit of study in a certain state, determining the probability of occurrence of some phenomenon. If the explained variable assumes two states, i.e., it indicates whether the studied phenomenon occurred or not, we are dealing with a binomial model. In the analysis, the explained variable took two values, hence the correct form was the binomial model. In addition, the binomial logit model allows to find statistically significant factors determining the probability of occurrence of some phenomenon and to examine the effects of interactions between these factors, and an additional advantage of the logit model is the ability to interpret its parameters. Accordingly, the data obtained from the questionnaire was analyzed using a logit model. The logit model is used to determine the probability of occurrence of a phenomenon. In this case, it is likely to use the P\&R parking during travel. If the explained variables are qualitative, their representatives in the model are zero-one variables (dichotomous variables). These variables take values in the model [83]:

$$
Y=\left\{\begin{array}{c}
1, \text { if the phenomenon occurs (the object has the feature) } \\
0, \text { if the phenomenon does not occur (the object has no eature). }
\end{array}\right.
$$

where $Y$-dependent variable.

The logit model for the dependent variable $Y$ is expressed as:

$$
p=P\left(Y=1 \mid X_{1}, \ldots X_{k}\right)=\frac{\exp \left(\beta_{0}+\sum_{i=1}^{k} \beta_{i} \cdot X_{i}\right)}{1+\exp \left(\beta_{0}+\sum_{i=1}^{k} \beta_{i} \cdot X_{i}\right)}
$$

where $p$-the probability of occurrence of a phenomenon, $X_{i}$-independent variable $(i=1 \ldots k)$, $\beta_{0}$-free expression and $\beta_{i}$-logistic regression coefficient.

The logit model (4) is transformed using logarithm to the following form:

$$
\operatorname{logit}(p)=\ln \frac{p}{1-p}=\beta_{0}+\beta_{1} \cdot X_{1}+\beta_{2} \cdot X_{2}+\cdots+\beta_{k} \cdot X_{k}
$$

Equation (5) is called the odds ratio and is expressed as the ratio of the probability that a phenomenon will occur to the probability that a phenomenon will not occur. 


\subsection{Logit Model Results}

The questions included in the questionnaire allowed for the selection of many explanatory (independent) variables, which were later used in the analysis to determine their impact (or no impact) on the $P \& R$ parking use by respondents. At the beginning of the analysis, all characteristics of the respondents were taken into account. To determine the probability of the P\&R parking use, the following variables were taken:

$Y-P \& R$ parking use,

$X_{1}$-gender,

$X_{2}$-age,

$X_{3}$ - education,

$X_{4}$-monthly income (Gross) [PLN],

$\mathrm{X}_{5}$-the number of years of having a driving license,

$X_{6}$-the average time spent traveling during a day,

$\mathrm{X}_{7}$ - the average number of trips made during a day,

$X_{8}$-the number of kilometers driven during a year,

$X_{9}$-trip purpose.

Independent variables $\left(X_{1}, \ldots, X_{9}\right)$ were selected using stepwise regression. Table 4 presents the variables after selecting, which were taken for the assessment of the P\&R parking in Cracow use $(Y)$. These variables characterized by a strong correlation with other variables, and a weak correlation with each other. The authors developed three models to describe the factors determining P\&R parking use. These are models A, B, and C. The first model (model A) took into account only characteristics of the respondents, i.e., gender, age, the number of years having a driving license, and monthly income. The model's form is presented below:

$$
\operatorname{logit}(p)=\beta_{0}+\beta_{1} \cdot X_{1}+\beta_{2} \cdot X_{2}+\beta_{4} \cdot X_{4}+\beta_{5} \cdot X_{5}
$$

where the meaning of symbols was explained at the beginning of the subsection.

Table 4. Independent variables adopted for assessing the P\&R parking use.

\begin{tabular}{|c|c|c|c|}
\hline No. & Variables & Characteristics & Symbol \\
\hline \multirow{2}{*}{1.} & \multirow{2}{*}{ Gender } & Male & 1 \\
\hline & & Female & 0 \\
\hline \multirow{2}{*}{2.} & \multirow{2}{*}{ Age [years] } & $18-44$ & 1 \\
\hline & & 45 and more & 0 \\
\hline \multirow{2}{*}{3.} & \multirow{2}{*}{ Monthly income (Gross) [PLN] } & 3000 and more & 1 \\
\hline & & Less than 3000 & 0 \\
\hline \multirow[b]{2}{*}{4.} & \multirow{2}{*}{ The number of years having a driving license [years] } & 6 and more & 1 \\
\hline & & Less than 6 & 0 \\
\hline \multirow{2}{*}{5.} & \multirow{2}{*}{ The average number of trips made during a day [trip] } & 4 and more & 1 \\
\hline & & From 1 to 3 & 0 \\
\hline \multirow{2}{*}{6.} & \multirow{2}{*}{ The number of kilometers driven during a year $[\mathrm{km}]$} & 20,000 and more & 1 \\
\hline & & Less than 20,000 & 0 \\
\hline \multirow{2}{*}{7.} & \multirow{2}{*}{ Trip purpose } & Optional & 1 \\
\hline & & Obligatory & 0 \\
\hline \multirow{2}{*}{8.} & \multirow{2}{*}{ P\&R parking use } & Yes & 1 \\
\hline & & No & 0 \\
\hline
\end{tabular}


The second model (model B) includes all variables that were taken for analysis and which are presented in Table 4. The model's form is presented below:

$$
\operatorname{logit}(p)=\beta_{0}+\beta_{1} \cdot X_{1}+\beta_{2} \cdot X_{2}+\beta_{3} \cdot X_{3}+\beta_{4} \cdot X_{4}+\beta_{5} \cdot X_{5}+\beta_{6} \cdot X_{6}+\beta_{7} \cdot X_{7}+\beta_{8} \cdot X_{8}+\beta_{9} \cdot X_{9}
$$

where the meaning of symbols was explained at the beginning of the subsection.

The third model (model C) includes only those variables for which the statistical significance values of the $p$-value test result from models $A$ and $B$ have a p-value $< \pm 0.1$. Higher values have been rejected because of the higher $p$-value, the lower the statistical significance of the coefficient. Hence, model $C$ took into account variables such as age, the number of years having a driving license, monthly income, and the number of trips made during a day by respondents. The model's form is presented below:

$$
\operatorname{logit}(p)=\beta_{0}+\beta_{2} \cdot X_{2}+\beta_{4} \cdot X_{4}+\beta_{5} \cdot X_{5}+\beta_{7} \cdot X_{7}
$$

where the meaning of symbols was explained at the beginning of the subsection.

Table 5 presents the results of the analyses.

\begin{tabular}{|c|c|c|c|c|c|c|}
\hline \multirow{2}{*}{ Model Variable } & \multicolumn{2}{|c|}{ Model A } & \multicolumn{2}{|c|}{ Model B } & \multicolumn{2}{|c|}{ Model C } \\
\hline & $\beta_{i}$ & $p$-Value & $\beta_{i}$ & $p$-Value & $\beta_{i}$ & $p$-Value \\
\hline Gender & -0.047 & 0.729 & 0.006 & 0.963 & & \\
\hline Age [years] & -0.650 & $0.000^{1}$ & -0.374 & 0.027 & -0.555 & $0.000^{1}$ \\
\hline Monthly income (Gross) & -0.407 & 0.002 & -0.387 & 0.003 & -0423 & 0.001 \\
\hline $\begin{array}{c}\text { The number of years having a } \\
\text { driving license }\end{array}$ & -0.344 & 0.036 & -0.279 & 0.092 & -0.351 & 0.031 \\
\hline $\begin{array}{l}\text { The average number of trips } \\
\text { made during a day }\end{array}$ & & & 0.464 & 0.003 & 0.214 & 0.147 \\
\hline $\begin{array}{c}\text { The number of kilometers driven } \\
\text { during a year }\end{array}$ & & & 0.131 & 0.322 & & \\
\hline Trip purpose & & & -0.017 & 0.905 & & \\
\hline Constant & 0.584 & 0.011 & 0.159 & 0.547 & 0.442 & 0.051 \\
\hline H.R. (hit ratio) & \multicolumn{2}{|c|}{$61.96 \%$} & \multicolumn{2}{|c|}{$60.05 \%$} & \multicolumn{2}{|c|}{$61.97 \%$} \\
\hline Log-likelihood & \multicolumn{2}{|c|}{-800.402} & \multicolumn{2}{|c|}{-784.209} & \multicolumn{2}{|c|}{$-799,417$} \\
\hline $\mathrm{R}^{2}(\mathrm{~N})$ & \multicolumn{2}{|c|}{0.037} & \multicolumn{2}{|c|}{0.039} & \multicolumn{2}{|c|}{0.039} \\
\hline
\end{tabular}

Table 5. Logit model results.

\section{Discussion}

In model $\mathrm{A}$, all coefficients with independent variables have negative values. The age of the respondents is the variable that has the greatest impact on P\&R parking use during travel. Then, the monthly income and the number of years having a driving license of the respondents affect respectively. In turn, the gender of respondents is the least important. This means that there is less likelihood that people aged from 18 to 44 who have a driving license of 6 years or more and their income is 3000 PLN ( $650 \Theta)$ or more will use the P\&R parking than other people.

In the case of model B, similarly as in model A, the age and monthly income of respondents are significant when choosing to use $P \& R$ parking during travel. In this model, the largest value of the coefficient is assumed by the variable regarding the average number of trips made during a day. This factor is positive, which means that people who travel on average four or more trips made during a day are more likely to use P\&R parking during travel. Gender, the number of years having a driving license, and trip purpose are of the least importance in model B.

Whereas in model $C$, age and monthly income have the greatest impact on the $P \& R$ parking use. The coefficients at the variables age, the number of years having a driving license, and monthly income are negative. This means that people between 18 and 4 years old who have a driving license six years 
or more and have monthly income of 3000 PLN ( 650 $\Theta)$ and more are less likely to use the P\&R parking. The coefficient at the variable characterizing the average number of trips made during a day is positive, which means that people who make four or more trips during a day are more likely to use the P\&R parking.

From the models presented in the article, model $\mathrm{C}$ has the highest hit ratio (H.R.), which is $61.97 \%$. H.R. value is above $50 \%$. It indicates that the assessment of users using the $P \& R$ parking during travel using model $\mathrm{C}$ is better than random. The ROC curve and the area under the curve were also used to assess the quality of the obtained logit models (Figure 16). ROC curves for models A, B, and C have a similar shape. The area under the ROC curve for each model is greater than $50 \%$. Model $C$ has a slightly larger area than in other cases. The variables were included in the model have a significant impact on the likelihood of using the P\&R parking. Therefore, model $C$ is a good tool for research related to P\&R parking use.

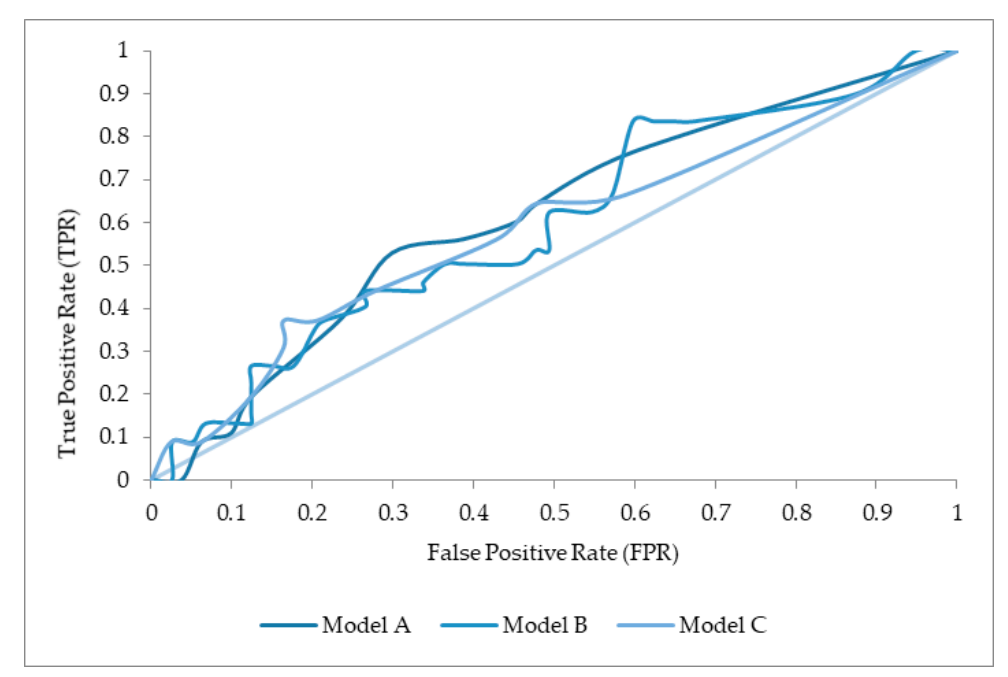

Figure 16. Deducted ROC graph from the models A, B, and C.

\section{Conclusions}

The article aimed to examine the features associated with the use of P\&R parking in Cracow (Poland). Analyzing data for the number of entries and exits of vehicles to/from individual parking locations, it can be stated that in all analyzed parking the most drivers park their cars on working days of the week. The results obtained are consistent with the results presented by i.a. Podoskiego [84], Gace et al. [85], Hamsa et al. [28] and Sharma et al. [86]. The results presented in these works also indicate that the largest number of people using $P \& R$ parking are commuters. In the case of months, the lowest number of parked vehicles occurs during the summer holiday months. Additionally, it can be observed that in the summer months the analyzed parking is characterized by a smaller parking space use than in other months of the year. In these months, traffic in the city is smaller, which may also be the reason for less parking use.

Analyzing the parking space use, it can be concluded that Kurdwanów P\&R parking featured the smallest parking space use in 2018. The reason may be that this parking opened in December 2017 and perhaps all users were not aware of its availability. Confirmation of this fact can be found in an analysis carried out for particular months because at the end of the year (from October) the number of vehicles parked in the parking is higher compared to other months. The parking space use in the other two parking sites is at a similar level, with slightly more use being observed in the Bieżanów P\&R parking compared to the Czerwone Maki P\&R parking. Differences in the parking space use in these two parking were in the summer months. The Bieżanów P\&R parking has a greater parking space use than the Czerwone Maki P\&R parking in these months. 
Public transport stops are located a short distance from the analyzed P\&R parking. In addition, the regulations for this type of parking use in Cracow (no parking fee for persons who have a ticket for public transport in Cracow) are to encourage people to leave their vehicles outside the city center at the P\&R parking and continue their journey using means of public transport.

In turn, the peak hour factor indicates in which periods of the day there is the most congestion in the parking associated with entries and exits parking. In the case of the Bieżanów P\&R parking, the maximum number of vehicle entries and exits to/from the parking is concentrated in one hour: entry-07:00-08:00, exit-16:00-17:00. A similar situation occurs in the case of the Kurdwanów P\&R parking-the maximum number of vehicles exits from the parking is concentrated in one hour: 16:00-17:00. However, the maximum number of vehicle entries into the parking is spread out over two hours: 06:00-08:00. In the Czerwone Maki P\&R parking the maximum number of entries and exits are spread out in two hours: entries-07:00-09:00, exits-16:00-18:00.

The results of surveys indicated that the majority of respondents are people who usually do not use P\&R parking in their travels. According to respondents, the most important element that would encourage people to use $P \& R$ parking more is the quality of public transport. The distances of the analyzed parking are not greater than $100 \mathrm{~m}$ from the nearest bus or tram stop. Only in the case of the Kurdwanów $P \& R$ parking, is the tram stop is about $110 \mathrm{~m}$ from the P\&R parking. In this case, the quality of public transport, to which respondents indicate, may also refer to the frequency of service, direct connections, or the cleanliness of public transport vehicles in Cracow.

The constructed logit models allowed the analysis of factors determining the P\&R parking use in Cracow. The analyses allow us to state that the choice of a $P \& R$ parking during travel is influenced by the age, number of years having a driving license, and monthly income (gross) of respondents. Gender, number of kilometers driven by car during a year, and trip purpose had the least impact on the P\&R parking use. He et al. [13] obtained similar results in their research. In their model, the factor that the most determine the P\&R parking use are the number of kilometers driven by car during a year and monthly income, whereas, in their model, age is less important than gender, the reverse of the research result presented in this article. In turn, in the work of Clayton et al. [87], the presented model indicates that the age of users is the factor with the greatest impact on the parking use, while monthly income has little impact. The differences in the impact of individual factors on the P\&R parking use that are presented in various papers may be due to the fact that the research was conducted in different countries around the world, where traffic participants are characterized by different behaviors, different levels of wealth and cities are characterized by different levels of road infrastructure and offer different (quantitative and qualitative) public transport. In addition, various authors included various independent variables in the modeling process.

Nevertheless, we assume that P\&R parking use is affected by other variables not included in the study. Therefore, further detailed research and analyses in this area are planned. However, the presented results constitute the basis for conducting further, more in-depth analyses based on a larger research sample, larger number of independent variables that may determine the $P \& R$ parking use as well as on a larger number of people who use P\&R parking in their travels.

Author Contributions: Conceptualization, E.M.; methodology, E.M.; validation, E.M.; formal analysis, E.M.; investigation, A.K.; resources, A.K.; data curation, A.K.; writing-original draft preparation, A.K.; writing一review and editing, E.M.; visualization, A.K.; supervision, E.M.; project administration, E.M. All authors have read and agreed to the published version of the manuscript.

Funding: This research received no external funding.

Acknowledgments: The authors wish to acknowledge Urban Infrastructure Company in Cracow (Poland) for providing access to data for research and analysis purposes as well as for their contributions in the understanding of the system. The authors would like to also thanks the Students, PhD Student, Graduate from Transport Systems and Traffic Engineering Department, Faculty of Transport and Aviation Engineering, Silesian University of Technology in Katowice who take part in field questionnaires survey collection.

Conflicts of Interest: The authors declare no conflict of interest. 


\section{References}

1. Karamychew, V.; Reeven, P. Park and Ride: Good for the city, good for the region? Reg. Sci. Urban Econ. 2011, 41, 455-464. [CrossRef]

2. Macioszek, E. First and last mile delivery problems and issues. In Advanced Solutions of Transport Systems for Growing Mobility. Advances in Intelligent Systems and Computing; Sierpiński, G., Ed.; Springer International Publishing: Cham, Switzerland, 2018; Volume 632, pp. 147-154. [CrossRef]

3. Noel, E.C. Park and ride: Alive, well and expanding in the United States. J. Urban Plan. Dev. 1988, 141, 2-13. [CrossRef]

4. Meek, S.; Ison, S.; Enoch, M. Park and Ride: Lessons from the UK experience. Transp. Res. Board 2008, 730, 1-18.

5. Parkhurst, G. Park and ride: Could it lead to an increase in car traffic? Transp. Policy 1995, 2, 15-23. [CrossRef]

6. Bos, I.; Molin, E. Is there a "Stick" Bonus? A Stated Choice Model for P\&R Patronage incorporating cross Effects. Eur. J. Transp. Infrastruct. Res. 2006, 6, 275-290. [CrossRef]

7. Qin, H.; Guan, H.; Wu, Y.J. Analysis of park and ride decision behavior based on Decision Field Theory. Transp. Res. Part F Traffic Psychol. Behav. 2013, 18, 199-212. [CrossRef]

8. Sharma, B.; Hickman, M.; Nassir, N. Park-and-ride lot choice model using random utility maximization and random regret minimization. Transportation 2019, 46, 217-232. [CrossRef]

9. Webb, A.; Khani, A. Park-and-Ride Choice Behavior in a Multimodal Network with Overlapping Routes. Transp. Res. Rec. 2020, 2674, 150-160. [CrossRef]

10. Islam, S.T.; Liu, Z.; Sarvi, M.; Zhu, T. Exploring Mode Change Behavior of Parn and Ride Users. Mat. Probl. Eng. 2015, 2015, 282750. [CrossRef]

11. He, B.H.; Wang, W.; Chen, J. A choice model of traveler preference for P\&R facilities. J. Harbin Inst. Technol. 2009, 4, 243-246.

12. Ying, H.; Xiang, H. Study on influence factors and demand willingness of Park and Ride. In Proceedings of the 2009 Second International Conference on Intelligent Computation Technology and Automation, Changsha, China, 10-11 October 2009; Volume 4, pp. 664-667. [CrossRef]

13. He, B.; He, W.; He, M. The attitude and preference of traveler to the Park \& Ride facilities: A case study in Nanjing, China. Procedia-Soc. Behav. Sci. 2012, 43, 294-301.

14. Zhao, X.; Li, Y.; Xia, H. Behavior decision model for park and ride facilities utilization. Adv. Mobil. Theor. Methodol. Appl. 2016, 9. [CrossRef]

15. Hole, A.R. Forecasting the demand for an employee Park and Ride service using commuters stated choices. Transp. Policy 2004, 11, 355-362. [CrossRef]

16. Qin, H.; Guan, H.; Zhang, G. Analysis of the travel intent for park and ride based on perception. Discret. Dyn. Nat. Soc. 2012, 2012, 1-14. [CrossRef]

17. Song, Z.; He, Y.; Zhang, L. Integrated planning of park and ride facilities and transit service. Transp. Res. Part C Emerg. Technol. 2017, 74, 182-195. [CrossRef]

18. Wang, J.Y.T.; Yang, H.; Lindsey, R. Locating and pricing park and ride facilities in a linear monocentric city with deterministic mode choice. Transp. Res. Part B Methodol. 2004, 38, 709-731. [CrossRef]

19. Fan, W.; Khan, M.B.; Ma, J.; Jiang, X. Bilevel programming model for locating park-and-ride facilities. J. Urban Plan. Dev. 2014, 140, 04014007. [CrossRef]

20. Khakbaz, A.; Nookabadi, A.S.; Shetab-bushehri, S.N. A model for locating park-and-ride facilities on urban networks based on maximizing flow capture: A case study of Isfahan, Iran. Netw. Spat. Econ. 2013, 13, 43-66. [CrossRef]

21. Alghazali, H.; Attya, H.; Al-Busaltan, S. Non-parametric Multi-criteria Optimisation of Park and Ride Facility Locations. IOP Conf. Ser. Mater. Sci. Eng. 2020, 671, 012095. [CrossRef]

22. Krasić, D.; Lanović, Z. Park \& Ride facility planning. Građevinar 2013, 65, 111-121.

23. Chen, X.Y.; Yang, X.K.; Xu, Z. Location Configuration Design of New Park-and-Ride Facilities in Beijing, China. In Proceedings of the CICTP 2012: Multimodal Transportation Systems-Convenient, Safe, Cost-Effective, Efficient, Beijing, China, 3-6 August 2012; Fang, F.C., Wei, H., Wang, Y., Zhang, J., Eds.; ASCE: Reston, VA, USA, 2012; pp. 11-22.

24. Szarata, A. Defining shape of membership function for Mamdani's Fuzzy Inference System within park \& ride share modelling. AIP Conf. Proc. 2015, 1648, 600004. 
25. Szarata, A. Modeling park and ride travel forecasting. Transp. Miej. i Reg. 2007, 7-8, 11-16.

26. Chen, Z.; Xia, J.C.; Irawan, B.; Caulfied, C. Development of location-based services for recommending departure stations to park and ride users. Transp. Res. Part C Emerg. Technol. 2014, 48, 256-268. [CrossRef]

27. Hamid, N.A. Utlizization patterns of park and ride facilities among Kuala Lumpur commuters. Transportation 2009, 36, 295-307. [CrossRef]

28. Kadar Hamsa, A.A.; Syed Adnan, S.A.A.; Khalid, U.A. Analysis of parking usage at the park and ride facility in Klang Valley, Malaysia. In Urban Transport; Brebbia, C.A., Ed.; Wessex Institute of Technology: Ashurst Lodge, Southampton, UK, 2014; Volume 20, pp. 179-193.

29. Khalid, U.A.; Hamsa, A.K.; Azeez, A. Parking utilization pattern of park and ride facility at public transportation terminals. In Proceedings of the Eastern Asia Society for Transportation Studies, Taipei, Taiwan, 9-12 September 2013; Volume 9, pp. 1-16.

30. Gan, H.; Wang, Q. Emissions impacts of the park-and-ride strategy: A case study in shanghai, China. Procedia Soc. Behav. Sci. 2013, 96, 1119-1126. [CrossRef]

31. Shirgaokar, M.; Deakin, E. Study of park-and-ride facilities and their use in the San Francisco Bay Area of California. Transp. Res. Rec. 2005, 1927, 46-54. [CrossRef]

32. Al-Kazily, J. Analysis of park-and-ride lot use in the sacramento region. Transp. Res. Rec. 1991, 1321, 1-6.

33. Kurek, A. Analysis of Transport Availability of Warsaw City. Master's Thesis, Supervisor: PhD. DSc. Eng. Elżbieta Macioszek, Prof. PŚ. Silesian University of Technology, Faculty of Transport and Aviation Engineering, Transport Systems and Traffic Engineering Department, Katowice, Poland, June 2019.

34. Kowalski, M.; Górecka, A. Problemy wykorzystania parkingów systemu P+ R w Warszawie. Logistyka 2014, 4, 3598-3606.

35. Bartel, I.; Duda, U.; Wiertel, B. Analiza i ocena funkcjonowania systemu" Parkuj i Jedź" w Krakowie. Transp. Miej. Reg. 2014, 6, 26-31.

36. Warsaw Public Transport Website. Available online: https://www.wtp.waw.pl/parkingi/\#ParkujP+R (accessed on 12 June 2020).

37. Urban Infrastructure in Cracow. Available online: http://mi.krakow.pl/parkingi/informacje-ogolne (accessed on 12 June 2020).

38. Road and City Maintenance Board in Wrocław. Available online: http://www.zdium.wroc.pl/kategoria/ parkowanie/parkingi-park-and-ride/ (accessed on 12 June 2020).

39. Municipal Transport Board in Poznan. Available online: https://www.ztm.poznan.pl/pl/komunikacja/parkuji-jedz/ (accessed on 12 June 2020).

40. Malopolska Agglomeration Cars. Available online: https://mka.malopolska.pl/documents/20182/42210/ Regulamin+i+Cennik+Parkuj+i+Jed\%C5\%BA/4b9d9d76-f4b0-484d-8143-e39b3f4abe17 (accessed on 12 June 2020).

41. City Board of Streets and Bridges in Tychy. Available online: https://mzuim.tychy.pl/parkride.php (accessed on 12 June 2020).

42. Brzeziński, A.; Jesionkiewicz-Niedzińska, K.; Rogala, A. Wady i zalety systemu Parkuj i jedź na przykładzie aglomeracji warszawskiej. Transp. Miej. Reg. 2013, 8, 4-9.

43. Parkitny, W. Model matematyczny wyboru lokalizacji miejsc przesiadkowych i parkingów dla systemu P \& R. In Zeszyty Naukowo-Techniczne Stowarzyszenia Inżynierów i Techników Komunikacji w Krakowie; Seria: Materiały Konferencyjne; Association of Communication Engineers and Technicians in Cracow: Cracow, Poland, 2007; Volume 80, pp. 137-146.

44. Wiśniewski, S. Lokalizacja parkingów Park and Ride w przestrzeni Łodzi. Probl. Rozw. Miast 2015, 4, $37-45$.

45. Czerwiński, S. System park and ride we Wrocławiu-przykład parkingu przy stadionie miejskim. Transp. Miej. Reg. 2013, 8, 10-18.

46. Fierek, S.; Bieńczak, M.; Zmuda-Trzebiatowski, P. Multiple criteria evaluation of P\&R lots location. Transp. Res. Procedia 2020, 47, 489-496.

47. Lower, A.; Lower, M.; Masztalski, R.; Szumilas, A. The Location of Park and Ride Facilities Using the Fuzzy Inference Model. Int. Sch. Sci. Res. Innov. 2015, 9, 1367-1374.

48. Szarata, A. Analysis of the size of Park and Ride car parks located in metropolitan areas. Constr. Archit. 2014, 13, 267-274, (In Polish: Szarata, A. Analiza wielkości parkingów Park and Ride zlokalizowanych w obszarach metropolitarnych. Bud. Archit. 2014, 13, 267-274). 
49. Szarata, A. Ocena efektywności funkcjonalnej parkingów przesiadkowych $(\mathrm{P}+\mathrm{R})$. Ph.D. Thesis, Cracow University of Technology, Cracow, Poland, 2005.

50. Szarata, A. Estimation of generalized cost in Park and Ride travels. Sci. Pap. Constr. 2003, 101, $399-406$.

51. Szarata, A. Impact of Park and Ride car parks on the section travel time in the street network-Comparison of analytical and simulation methods. Sci. Noteb. Constr. 2004, 102, 511-518.

52. Central Statistical Office. Available online: https://stat.gov.pl/ (accessed on 7 November 2019).

53. Open Street Map. Available online: https://www.openstreetmap.org/\#map=6/51.507/21.560 (accessed on 8 November 2019).

54. Cracow City Council. Resolution No. LVII/762/12 of the Crakow City Council Regarding the Regulations for the Use of Parking Lots Operating in the Park and Ride $(P+R)$ System in Cracow; Cracow City Council: Cracow, Poland.

55. Mi Cracow. Available online: http://mi.krakow.pl/parkingi/informacje-ogolne (accessed on 4 November 2019).

56. Carmines, E.G.; Zeller, R.A. Reliability and Validity Assessment; Sage Publications: New York, NY, USA, 1982.

57. Cronbach, L.J. Coefficient alpha and the internal structure of tests. Psychometrica 1951, 16, 297-334. [CrossRef]

58. Yurdugul, H. Minimum sample size for Cronbach's coefficient alpha: A Monte-Carlo study. Hacet. Univ. J. Educ. 2008, 35, 397-405.

59. Cortina, J.M. What is Coefficient Alpha? An Examination of Theory and Applications. J. Appl. Psychol. 1993, 78, 98-104. [CrossRef]

60. Streiner, D. Starting at the beginning: An introduction to coefficient alpha and internal consistency. J. Personal. Assess. 2003, 80, 99-103. [CrossRef] [PubMed]

61. Tavakol, M.; Dennick, R. Making sense of Cronbach's alpha. Int. J. Med Educ. 2011, 2, 53-55. [CrossRef] [PubMed]

62. Macioszek, E.; Świerk, P.; Kurek, A. The Bike-Sharing System as an Element of Enhancing Sustainable Mobility-A Case Study based on a City in Poland. Sustainability 2020, 12, 3285. [CrossRef]

63. Allen, E.; Seaman, C.A. Likert Scales and Data Analyses. Qual. Prog. 2007. Available online: http://rube.asq. org/quality-progress/2007/07/statistics/likert-scales-and-data-analyses.html (accessed on 1 February 2019).

64. Boone, H.N.; Boone, D.A. Analyzing Likert Data. J. Ext. 2012, 50, 1-5.

65. Jamieson, S. Likert scales: How to (ab) use them. Med Educ. 2004, 38, 1212-1218. [CrossRef]

66. Survey Online. Available online: https://www.survio.com/pl/ (accessed on 12 March 2020).

67. Christensen, R. Log-Linear Models and Logistic Regression; Springer Science \& Business Media: New York, NY, USA, 2006.

68. Hilbe, J.M. Logistic Regression Models; CRC Press: Boca Raton, FL, USA, 2009.

69. Hosme, D.W.; Lemeshow, A. Applied Logistic Regression; A Wiley-Interscience Publication: Hoboken, NJ, USA, 2000.

70. Tarko, A.P.; Perez-Cartagena, R.I. Variability of peak hour factor at intersections. Transp. Res. Rec. 2005, 1920, 125-130. [CrossRef]

71. Akçelik, R.; Rouphail, N.M. Estimation of delays at traffic signals for variable demand conditions. Transp. Res. Part B Methodol. 1993, 27, 109-131. [CrossRef]

72. Levinson, H.S.; Sullivan, D.; Bryson, R.W. Effects of urban traffic volume variations on service levels. In Proceedings of the Transportation Research Board 85th Annual Meeting, Washington DC, USA, 22-26 January 2006.

73. Macioszek, E. The application of HCM 2010 in the determination of capacity of traffic lanes at turbo roundabout entries. Transp. Probl. 2016, 11, 77-89. [CrossRef]

74. Szczuraszek, T.; Macioszek, E. Analiza rozkładów odstępów czasu pomiędzy pojazdami na obwiedni małych rond. Drog. Imosty Inst. Badaw. Dróg Most. 2010, 3, 87-99.

75. Macioszek, E. Roundabout entry capacity calculation-A case study based on roundabouts in Tokyo, Japan, and Tokyo surroundings. Sustainability 2020, 12, 1533. [CrossRef]

76. Macioszek, E. The comparison of models for follow-up headway at roundabouts. In Recent Advances in Traffic Engineering for Transport Networks and Systems. Lecture Notes in Networks and Systems; Macioszek, E., Sierpiński, G., Eds.; Springer International Publishing: Cham, Switzerland, 2018; Volume 21, pp. 16-26. [CrossRef]

77. Macioszek, E. The Comparison of Models for Critical Headways Estimation at Roundabouts. In Contemporary Challenges of Transport Systems and Traffic Engineering. Lecture Notes in Networks and Systems; Macioszek, E., 
Sierpiński, G., Eds.; Springer International Publishing: Cham, Switzerland, 2017; Volume 2, pp. 205-219. [CrossRef]

78. Macioszek, E. Analysis of Significance of Differences Between Psychotechnical Parameters for Drivers at the Entries to One-lane and Turbo Roundabouts in Poland. In Intelligent Transport Systems and Travel Behaviour. Advances in Intelligent Systems and Computing; Sierpiński, G., Ed.; Springer International Publishing: Cham, Switzerland, 2017; Volume 505. [CrossRef]

79. Bassan, S. Modeling of peak hour factor on highways and arterials. KSCE J. Civ. Eng. 2013, 17, $224-232$. [CrossRef]

80. Polus, A.; Kikuchi, S. Sampling and Evaluation of Peak Hour Factor Characteristics; University of Delaware, Delaware Transportation Center: Newark, DE, USA, 1989.

81. Lan, C.J.; Abia, S.D. Determining peak hour factors for capacity analysis. J. Transp. Eng. 2010, 137, 520-526. [CrossRef]

82. Yu, W.; Bai, H.; Chen, J.; Yan, X. Analysis of space-time variation of passenger flow and commuting characteristics of residents using smart card data of Nanjing Metro. Sustainability 2019, 11, 4989. [CrossRef]

83. Cieślak, M. Prognozowanie Gospodarcze: Metody i Zastosowania; Wydawnictwo Naukowe PWN: Polska, Poland, 2008.

84. Podoski, J. Transport w Miastach; Wydawnictwa Komunikacji i Łączności: Polska, Poland, 1985.

85. Gaca, S.; Suchorzewski, W.; Tracz, M. Inżynieria Ruchu Drogowego; Wydawnictwa Komunikacji i Łączności: Polska, Poland, 2009.

86. Sharma, B.; Hickman, M.; Nassir, N. A study on the utilization of Park-and-Ride lots in South East Queensland. In Proceedings of the 38th Australasian Transport Research Forum, Melbourne, Australia, 16-18 November 2016.

87. Clayton, W.L.; Ben-Elia, E.; Parkhurst, G.; Ricci, M. Where to park? A behavioural comparison of bus Park and Ride and city centre car park usage in Bath, UK. J. Transp. Geogr. 2014, 36, 124-133. [CrossRef]

(C) 2020 by the authors. Licensee MDPI, Basel, Switzerland. This article is an open access article distributed under the terms and conditions of the Creative Commons Attribution (CC BY) license (http://creativecommons.org/licenses/by/4.0/). 